\title{
A Journey to the West: The Ancient Dispersal of Rice Out of East Asia
}

\author{
Robert N. Spengler III ${ }^{* *}$ (D) Sören Stark², Xinying Zhou ${ }^{3,4,5}$, Daniel Fuks ${ }^{6,7}$, Li Tang $^{1}$, Basira Mir-Makhamad ${ }^{1}$, \\ Rasmus Bjørn ${ }^{1}$, Hongen Jiang ${ }^{3}$, Luca M. Olivieri ${ }^{8,9}$, Alisher Begmatov ${ }^{10}$ and Nicole Boivin ${ }^{1,11,12,13}$
}

\begin{abstract}
Rice is one of the most culturally valued and widely grown crops in the world today, and extensive research over the past decade has clarified much of the narrative of its domestication and early spread across East and South Asia. However, the timing and routes of its dispersal into West Asia and Europe, through which rice eventually became an important ingredient in global cuisines, has remained less clear. In this article, we discuss the piecemeal, but growing, archaeobotanical data for rice in West Asia. We also integrate written sources, linguistic data, and ethnohistoric analogies, in order to better understand the adoption of rice outside its regions of origin. The human-mediated westward spread of rice proceeded gradually, while its social standing and culinary uses repeatedly changing over time and place. Rice was present in West Asia and Europe by the tail end of the first millennium BC, but did not become a significant crop in West Asia until the past few centuries. Complementary historical, linguistic, and archaeobotanical data illustrate two separate and roughly contemporaneous routes of westward dispersal, one along the South Asian coast and the other through Silk Road trade. By better understanding the adoption of this water-demanding crop in the arid regions of West Asia, we explore an important chapter in human adaptation and agricultural decision making.
\end{abstract}

Keywords: Rice, Paddy farming, West Asia, Archaeobotany, Agricultural intensification, Crop exchange

\section{Introduction}

Asian rice (Oryza sativa) is currently the second mostconsumed food crop by humans, after wheat (Triticum aestivum), and a major global primary commodity (FAO 2020). The intensification of rice cultivation, along with maize (Zea mays) and wheat, fueled major demographic transition of the past ten millennia (Ammerman and Cavalli-Sforza 1984; Bocquet-Appel 2011; Gowdy and Krall 2014; Omrak et al. 2016; Brace et al. 2019; Soares et al. 2019). Rice's global economic importance is perhaps all the more impressive considering that its westward spread through Eurasia began several millennia after wheat's eastward diffusion from southwest Asia, the latter process spanning from roughly 6500 to $2500 \mathrm{BC}$

\footnotetext{
*Correspondence: spengler@shh.mpg.de

${ }^{1}$ Department of Archaeology, Max Planck Institute for the Science

of Human History, Jena, Thuringia, Germany

Full list of author information is available at the end of the article
}

(Zohary 1998). Archaeobotanists have elucidated much of the path towards initial domestication, dispersal, and intensification of cultivation. However, the timing and specific routes of dispersal of rice out of East Asia remain elusive, due in part to a dearth of data from early historical periods in West Asia. In this paper, we trace what appears to be two roughly contemporaneous and parallel westward dispersals. One across the Silk Road through the southern mountains and arid Central Asia, and another through South Asian nautical trade, i.e. the Sea Links or maritime routes across the Indian Ocean along the Red Sea and Mediterranean, to Europe. Rice is a water-demanding crop and its spread into West Asia has been argued to coincide with greater collective investment in irrigation and shifting culinary practices (Watson 1983). By tracing the route of dispersal westward for this key global staple, we seek to better understand the processes that led to the modern cultural, demographic, and economic world. 
While there have been many attempts to synthesize the early narrative of rice domestication and dispersal, notably Fuller (2011a) in the journal Rice, all of these end at the deserts or mountains of West Asia. One of the most fascinating and least studied chapters in the story of rice starts when it leaves its East Asian origins and spreads into arid West Asia and through the Red and Mediterranean Seas (Nesbitt et al. 2010; Muthukumaran 2014; Van Der Veen and Morales 2015; Reed and Leleković 2019). With increasing discovery of archaeobotanical rice remains from West Asia and Europe, it is worth exploring what we can say about the social implications of its spread. Rice is an inseparable part of cuisines from Xinjiang to Azerbaijan; it plays an important role in the economy in arid regions of the Arabian Peninsula, North Africa, and across the Iranian Plateau. Likewise, versions of pilaf (palov, palau, plov, etc.), are served across West Asia, Eastern Europe, and North Africa today (Nesbitt et al. 2010; Muthukumaran 2014). Pilaf is a symbol of national identity for people from Uzbekistan and Afghanistan to Morocco; while there are many regional derivatives, the core ingredient is always rice. Summer paddy rice cultivation is still practiced in some of the most arid regions of West Asia, notably in Mazandaran and Gilan, Iran, as well as Zanjan, Golestan, Khuzestan, Esfahan, Fars, and Khorasan, with valuable water in oases being diverted towards rice rather than arid-land-adapted crops (Nesbitt et al. 2010). Understanding how and when rice traversed two continents, informs us about adaptive strategies, culinary choices, and globalization in the ancient world.

\section{Domestication}

Despite major scientific advances in the past few years, rice domestication remains a topic of debate. We present a brief summary of current views here, but more detailed summaries have been published elsewhere. Two clear genetic and phenotypic lineages of rice exist, O. sativa ssp. japonica in East Asia and O. sativa ssp. indica in South Asia (Civán et al. 2015; Castillo et al. 2016), evolving from two different progenitors, O. nivara (indica) and O. rufipogon (japonica) (Kawakami et al. 2007). However, the origin story is complicated by the fact that several alleles associated with domestication are shared in common between the two lineages, a realization that has led scholars to suggest that domestication may be linked to hybridization (Kovach et al. 2007). Current consensus among scholars suggests that two lineages were independently brought under cultivation, one in northern India and one in eastern China (Fuller et al. 2010; Fuller 2011a, b; Gross and Zhao 2014; Castillo et al. 2016). In this model, the traits of domestication, notably a tougher rachis (the sh 4 allele), evolved only once in a cultivated population in East Asia, and humans dispersed the domesticated morphotype across the continent more than five millennia ago. Subsequent studies have also suggested hybridization with repeated back crossing (McNally et al. 2009). When and how this original hybridization occurred remains poorly understood and requires further research.

\section{East Asia}

The origins of East Asian rice are more clearly understood than the South Asian lineage, benefiting from an immense wave of archaeobotanical investigation. Rice was likely collected from the wild by seed foragers for millennia before it was cultivated (Gross and Zhao 2014). Evidence has been presented for more targeted rice foraging by 8000 years ago along the lower Yangtze River (Zhao 2011). Tianloushan and Hemudu in the Yangtze floodplain have provided some of the earliest evidence for cultivation and illustrate that rice was still a minor component in a more complex foraging strategy that included fruits and nuts (Fuller et al. 2009). The increased focus on rice in the economy only took place within the past five thousand years. Rice cultivation spread into the middle and upper Yangtze region by 6000 BC (Zhang et al. 2012; Jin et al. 2014; He et al. 2017; Lu 2017). Fuller et al. (2007) argue that non-shattering spikelets of rice were not fixed into the population until after $5000 \mathrm{BC}$, with full populations of domesticated rachises reported by 4000 BC (Fuller et al. 2009, 2014). Supporting this conclusion, rice spikelet bases from Kuahuqiao (6000$5400 \mathrm{BC}$ ) were primarily of a wild morphotype (Zheng et al. 2004). At the site of Huxi, non-shattering spikelet bases have been recorded, dating to $6500 \mathrm{BC}$, and possibly represent the oldest evidence for a beginning of the domestication (Zheng et al. 2016). These close analyses of diachronic phenotypic change in rachis structure appear to call earlier claims of domestication based on phytoliths into question (e.g. Liu 2004; Jiang and Liu 2006). Despite the seemingly clear sequence for morphological change through time, subsequent phytolith studies have also claimed earlier dates for rice domestication and dispersal (Zhang et al. 2010; Zuo et al. 2017).

Archaeobotanists have argued for a rapid northward and westward dispersal of rice into the Guanzhong Plain and the Hehuang region of Gansu (Zhang et al. 2010, 2012; Jin et al. 2014). Current evidence seems to imply a slightly later dispersal south and west (Chen et al. 2020; He et al. 2017). Deng et al. (2018) recently claimed to identify domesticated rice bulliform phytoliths in eastern Taiwan at Chaolaiqiao from 4200 years ago. Rice cultivation appears to have made it to the Sichuan Plains at Baodun and Guiyanqiao by more than 4000 years ago (d'Alpoim Guedes et al. 2013) and into Yunnan at 
Baiyangcun by 2640 BC (Dal Martello et al. 2018). The lack of early archaeobotanical evidence for rice in the Hexi Corridor or northern Central Asia, has led scholars to suggest that ecological constraints would have hampered a northern dispersal (Chen et al. 2020). Increasingly, scholars are accepting a demic expansion model, suggesting that grain surplus allowed for the growth and spread of farming populations along with cultivation techniques across Asia (Fuller 2011b; Cobo et al. 2019).

\section{South Asia}

Indian rice domestication has been a topic of extensive inquiry over the last two decades (Fuller and Madella 2002; Saraswat 2005; Fuller 2005, 2006, 2011a; Tewari et al. 2008; Fuller et al. 2010; Bates et al. 2016, 2017a; Petrie and Bates 2017). As in East Asia, phytoliths have been used in South Asia to argue for rice cultivation and domestication thousands of years earlier than evidenced by archaeobotanical remains. Notably, phytoliths from a $2.8 \mathrm{~m}$-deep lake-profile trench at Lahuradewa in Uttar Pardesh have been used to argue for wild rice harvesting by $8300 \mathrm{BC}$ and full cultivation by $5000 \mathrm{BC}$ (Saxena et al. 2006); these early dates have been repeatedly referenced (Saraswat 2005; Saxena et al. 2006; Pokharia et al. 2017). Charred rice grains were found in the earliest phase of Lahuradewa, site phase 1A (ca. $6400 \mathrm{BC}$ ), and using morphometrics Tewari et al. (2008) argued that these grains were domesticated. Many scholars are highly critical of these early rice dates, notably regarding their domesticated status (Fuller 2002; Harvey et al. 2005; Possehl 1999). Scholars have questioned the reliability of the domestication status of rice phytoliths at other sites in South Asia as well (Fujiwara et al. 1992; Fujiwara 1993; Fuller and Madella 2002; Bates et al. 2016, Bates and Petrie 2016). Deng et al. (2018) illustrate how widely varying in morphology rice bulliform phytoliths can be, even within a single population.

More secure evidence for rice consumption and harvesting, either wild or cultivated, comes from several second and late third millennium BC sites (Harvey and Fuller 2005; Saraswat 2005; Fuller 2011a; Bates et al. 2016, 2017a; Stevens et al. 2016; Petrie and Bates 2017). The first evidence for the increase and concentration of human populations and the formation of villages in the Ganges, Punjab, Harayana, and Swat dates to roughly 2500 BC and coincides with archaeobotancial rice remains (Costantini 1987; Saraswat and Pokharia 2003; Fuller 2006; Harvey et al. 2005; Fuller 2011b; Silva et al. 2015). Rice cultivation was well-established across the Ganges region by the mid-third millennium $\mathrm{BC}$ and much of India and southeast Asia by the mid-second millennium BC (Fuller 2002, 2005, 2006, 2011a; Fuller and Madella 2002; Saraswat 2005; Tewari et al. 2008; Fuller and Qin 2009; Fuller et al. 2010; Madella 2014; Silva et al. 2018). Its significance as a summer crop in seasonal rotation systems appears to have been geographically variable, and scholars have noted that farming systems across India were dynamic through time and space (Petrie and Bates 2017; Bates et al. 2017b).

\section{Himalayan Plateau}

Considerable focus has been placed on a rice dispersal route across southern South Asia (Fuller 2011a, b; Castillo et al. 2016; Stevens et al. 2016), although Stevens et al. (2016; Fuller 2011a) cautiously entertain a northerly route, noting there is no genetic signature of japonica in the greatest rice-growing regions of Myanmar, Assam, and Bengal. They state, "for rice, as with Chinese millet entry from the northwest is suggested by the admittedly patchy data, but we would stress the need for increased archaeobotanical sampling around both northwest and northeast South Asia and throughout the Himalayas" (Stevens et al. 2016:1550). In between the northern and southern routes, many scholars have proposed that East Asian rice first dispersed into northwestern India through mountain passes along rich river valleys (Vaughan et al. 2008; Vidale et al. 2011; Huang et al. 2012; Chen et al. 2020), such as Kashmir, where early rice impressions in ceramics are reported (Costantini 1987).

East Asian style harvesting knives, jade and other stone objects, and tripod ceramic vessels appear in this region in the third and second millennia $\mathrm{BC}$; these artifacts are emblematic of cultural dispersal from the east (Stacul 1976, 1993; Sharif and Thapar 1992; Fairservis 1975; Han 2012; Coningham and Young 2015). This "Chinese Horizon" may mark the introduction of japonica rice along with peaches (Prunus persica) and apricots (P. armeniaca) from East Asia (Fuller 2006; Fuller et al. 2010; Boivin et al. 2012; Stevens et al. 2016). Human aDNA suggests that the southern Himalaya served as a genetic barrier to low-elevation populations, which were not physiologically adapted to hypoxia and other ecological constraints (Jeong et al. 2016). Recent genetic studies also suggest long periods of population continuity in rich mountain valleys, notably the Swat Valley (Narasimhan et al. 2019). Despite a lack of evidence for human genetic movements through the southern Himalayan valleys, there is considerable evidence for the movement of goods and crops (Spengler et al. 2020). Discussions of crop dispersal in this region are often closely linked to the concept of a "Northern Neolithic", suggesting that a unique developmental trajectory was followed by farmers in Swat and Kashmir (Betts et al. 2019). The presence of rice in these valleys by the late second or first millennium BC means that people living in areas in the mountain foothills-in some cases where rice cannot grow today-were 
responsible for transporting viable seeds over thousands of kilometers (Fuller 2011a). Recent archaeobotanical research on the Himalayan Plateau has led to the identification of early rice remains at high elevations, above its growing zone, suggesting that small-quantities of rice might have been transported over short distances. The site of Kaerdong (also referred to as Kyung-lung Mesa; 4300 masl) is thought to have had a relationship with the Zhangzhung (500 BC-AD 625), a pre-Buddhist kingdom in the western Himalayas (Aldenderfer and Olsen 2008). Abundant archaeobotanical remains were collected from test trenches in 2004 and 2013. A single rice grain was recently recovered in association with a barley grain that was directly dated to between AD 455 and 700. Surprisingly, the researchers report nine rice spikelet bases from different layers, which may suggest that rice was consumed by higher status individuals and the grains were carried to higher elevations un-threshed (Song et al. 2018). Rice grains were also recovered from the nearby large-scale settlement of Zebang (4100 masl), which dates to roughly the same period (Song et al. 2018).

Rice was reported at Semthan in Kashmir dating between 1500 and $500 \mathrm{BC}$ (Lone et al. 1993), and from the later phases at Gufkral and Burzahom also in the Kashmir Valley (ca. 1800-1000 BC; Kajale 1982; Lone et al. 1993). Although, Pokharia et al. (2018) note that there is some question about the exact stratigraphic context of the rice grains at these sites. The dense archaeological deposits in the valleys of Kashmir, Kapisa, and Swat in the western Himalayan-Hindu Kush region of India, Pakistan and Afghanistan illustrate that people were concentrating in these ecologically rich orographic zones and that the passes served as corridors of exchange from the third millennium BC until today (Bandey 2009; Han 2012; Coningham and Young 2015; Vidale et al. 2015; Olivieri 2018; Olivieri et al. 2019). Archaeologists have argued for an established farming system in the Swat Valley at least by the beginning of the second millennium $\mathrm{BC}$, based on archaeological data and material culture and expansion of settlement size, as well as from inferred data such as the apparent demographic shifts (Vidale et al. 2011). In the second millennium BC geometric rock-art depictions of Swat have been interpreted as field cultivation scenes (Vidale and Olivieri 2002; Vidale et al. 2011).

Agricultural tools have been recovered in Swat notably the so-called 'perforated knives' of the Northern Neolithic, as well as saddle-shaped querns (Vidale et al. 2011). Domesticated zebu are also attested, at least since the third millennium BC (Costantini 1987). Since protohistory, and until pre-modern times, the surplus of rice and other cereals from Swat was exported to the major centers of the plain of Gandhara (Olivieri, 2020). An intensive and complex agricultural system was recently identified at the multiphase site of Barikot in the studied period (ca. 1200 BC-50 AD) in the Swat Valley (Olivieri et al. 2019), whereas rice was likely a summer crop in a mixed cropping system (Spengler et al. 2020; Fig. 2h, j). The diversity of different crops in the Barikot assemblage is reflective of the unique cultivation conditions in the valley, allowing warmer-weather crops, characteristic of the Indus, to grow further north. While it is unlikely that rice at Barikot represents the earliest remains in the region, it shows that rice was a well-established part of the farming system in these mountain valleys before the tail end of the second through the first millennia BC.

\section{West and Central Asia}

\section{Historical Sources}

Linguistics can clarify some of the contours of the trajectories of dispersal. The majority of words for rice in Central Asia are, ultimately, borrowed from a form similar to Old Chinese "brêh 'fine rice' (cf. Witzel 1995: 102), and shows up in two distinct yet obviously related forms: in the south and east as Vedic vrïhi- and Pashto wriže (cf. also in the isolate Burushaski brás and briu, where the exact origin remains elusive), and in the west as Persian brinj and gurinj (Mayrhofer 1976: 282). In Ancient Greek orindas ('rice cake') reflects the western form, and the generic term oryza ('rice grain') is a borrowing of the eastern variant, which also lies behind English rice, Khotanese rrìysu, and Yaghnobi rijan (Chantraine 1968: 820, 828 ). The western word also continues in the various Turkic languages that borrowed the Iranian forms (e.g. Turkish pirinc, Kazak kürish, and Uighur gurunj; Bailey 1979: 364). While the Iranian word entered the Tarim Basin from the west (Khotanese), there is a distinct eastern word for rice that appears in local Tocharian languages (Tocharian A and B klu) that must derive from another Sinitic word (Old Chinese [l] $u$ ? [unhusked rice]; Peyrot 2018: 254-255), suggesting two distinct entries to eastern Central Asia. Another term for rice, which is prevalent across Central Eurasian languages (mainly Iranian and Turkic), ša $\bar{l} \bar{\imath}$ specifically refers to unhusked rice. This term is likely borrowed from Sanskrit śáli- (Morgenstierne 2003: 78), where it in turn represents a local borrowing (Mayrhofer 1976: 632).

The most frequently cited text associated with the dispersal of rice into West Asia is The Records of the Great Historian, the Shiji (Sima 1993 [109-91 BC]: Book 123: 3160). Zhang Qian, the first Han ambassador to the 'Western Regions', is credited with having reported that rice was cultivated in Dayuan, 大宛, (as well as Parthia and Chaldea, mentioned below), according to most scholars the historical region of Ferghana. There are few written indications of rice in western Central Asia over the 
following 500 years, but this may be due to the general dearth of written sources. There is a mention of rice fields in Dayuan in the Jinshu (Fang 1974 [AD 265-420]: Volume 97: 2542), but some parts of the Book of Jin appear to be transmitted from the earlier Shiji. Rice does not appear in Avestan texts (although, only a handful of plants are mentioned in those texts; Boyce 1979), nor is it among the grains that Herodotus mentioned growing in Persia (Herodotus 1987 [440 BC]). Likewise, it was stated in the Weishu (Wei 2018 [AD 551-554]: Volume 102: 2271) that no rice was grown in Bosi, an account likely gathered by a Northern Wei embassy in AD 436 (Agostini and Stark 2016). This statement is simply repeated in the Beishi ( $\mathrm{Li}$ 2018 [AD 643-659]: Volume 97: 3222) and the Zhoushu (Linghu 2018 [AD 636]; Volume 50: 920), suggesting that rice was still rare across southwest Asia. Moreover, rice is not attested in the Aramaic documents from ancient Bactria (modern Turkmenistan; fourth century BC) and in any Bactrian documents (fourth to eight centuries $\mathrm{AD}$ ), in which wheat, barley, and millet are cited (Naveh and Shaked 2012; Sims-Williams 2012). Rice is also lacking in the economic Sogdian documents from Mugh in the Upper Zerafshan Valley (early eighth century AD), in which various kinds of grains are discussed in great length (Bogolyubov and Smirnova 1963).

In the fifth century $\mathrm{AD}$, the Weishu references rice cultivation across several regions of Central Asia, including: (1) Nakhshab (Nuoseboluo 諾色波羅) in the Lower Kashka-Darya (Volume 102: 2273); (2) Kabudhan (Jiabudan 伽不單) in the Bulungur zone of the Samarkand Oasis (Volume 102: 2273); and (3) possibly also in Bukhara. Although, the claim for Bukhara is only indirect, as rice is only mentioned in relation to the small principality of Zaojiazhi (早伽至) west of Bukhara (Niumi 忸密), as we note below, this may be Paykend (Weishu, Volume 102:2273). Records from the Chinese travelers, Xuanzang and Hyecho, recorded local foods and rice seldom appears, but they note that Persians favored bread. The Hulin (Tang period; AD 618-907) notes that the Sogdians cooked the dish Hualuo (in Middle Chinese this probably sounded somewhat closer to pilaf). The Weishu accounts were likely gathered by a Northern Wei envoy to Ferghana and Chach (the area around modern Tashkent) in AD 437 (Yu 2013). Although, as mentioned above, rice is not attested in Sogdian economic documents, historians note two different terms for rice, Brinj (brync) and $r \bar{i} z \bar{a}(r y z ' k h)$, in the Sogdian Buddhist and Manichaean texts (Benveniste 1940: 48). The former is a loanword from Middle Persian. The latter is a cognate of a widely spread term in many European languages. In addition, Sogdian historians note a term for a rice field, $r y z^{\prime} k h$ 'stny (Benveniste 1940: 48). Rice likely reached Sogdiana from the south (from Bactria, Gandhara, and northern
India) - this is suggested by the fact that rice is mentioned in Sogdiana, but not in Chach (Zheshe 者舌), and the southern origin of the etymon-perhaps as a result of Sogdian commerce with northern India, or as a result of political and cultural connections with the regions to the south during the Hunnic period (Kidarite and Hephthalite rule in Sogdiana, Bactria, and Gandhara-see Alram 2016). The different word for rice in the autochthonous Tocharian languages of the Tarim Basin suggests that it is less likely that rice dispersed with Sogdian diaspora communities. As a final note, the state of Zaojiazhi, 早 伽至, from the Weishu, Chapter 102 (ca. AD 437), supposedly had only a "few agricultural fields" so that "rice and wheat are imported from the neighboring countries". Arguably, the text refers to Paykend, where rice may have been imported, and where recent archaeobotanical finds of rice are discussed below.

\section{Archaeobotanical Data}

Today, rice is grown in parts of the Zerafshan Valley in Uzbekistan and in some particularly humid river valleys as far north as the southeastern corner of Kazakhstan. Recently, early rice grains were reported by Chen et al. (2020) from the site of Khalchayan. Two wellpreserved grains (Fig. 2g) were recovered from the site, located along the Surkhan River of southeastern Uzbekistan. These two grains came from an ash pit located in an architectural complex that the excavators refer to as a dynastic shrine (Chen et al. 2020). The complex contained numerous artifacts that clearly express its elite standing, including coins, ceramic sculptures, and wall paintings. The two grains were directly dated to cal AD 230-416. The Surkandarya Region is a rich agricultural zone today and was likely far more prosperous in the past when glacial melt streams fed into the main artery of the Surkhan River throughout the summer. There is a published claim from a Soviet excavation in the 1970s that a large quantity of rice grains was recovered from one site in a cluster of sites alled the Nos 28, 29, and 61 group (Fig. 1) in Ferghana, dating to the early first millennium AD (Gorbunova 1986). Rice grains were also reported to have been recovered from mudbrick fragments at Munchak Tepe (fifth to seventh century AD) (Gorbunova 1986) in the Osh Region of Kyrgyzstan near the modern town of Kerkidon (Brykina 1974).

Desiccated grains of rice dating to the second half of the first millennium AD have also been reported from the Astana Cemetery in the Turpan region of Xinjiang (Chen et al. 2012; Fig. 2k-m). All of the grains from the Astana burial had their husks articulated and were located in the bottom of a ceramic pot, mixed with broomcorn and foxtail millet (Setaria italica) and bread wheat, as well as a few seeds of Echinochloa crus-gali, Vaccaria segetalis, 


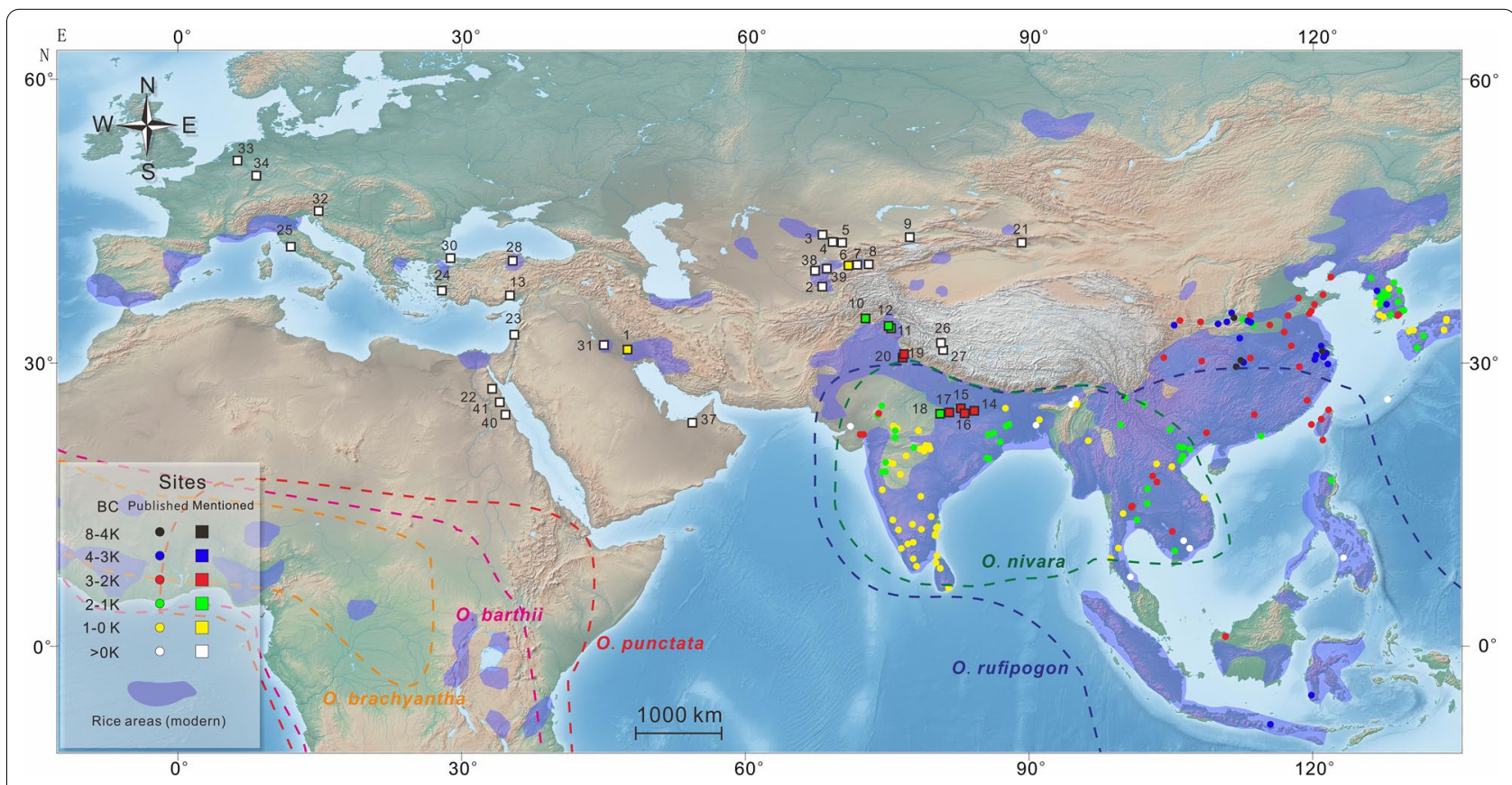

Fig. 1 Map illustrating the ancient dispersal of rice; blue shaded areas represent the range of modern rice cultivation as modified from Ray et al. (2012); modern range of wild rice species are indicated by dotted lines; (1) Susa (Strabo 1924 [7 BC-AD 23]; Miller 1981); (2) Khalchayan ca. AD 250 (Chen et al. 2020); (3) Konyr-tobe, seventh century AD (Bashtannik 2008); (4) Karaspan-tobe, fourth to fifth century AD (Bashtannik 2008); (5) Djuvan-tobe, seventh century AD (Bashtannik 2008); (6) Khujand (Sima 1993 [91-109 BC]); (7) Nos 28, 29, and 61, early first millennium AD (Gorbunova 1986); (8) Munchak Tepe, fifth to seventh centuries AD (Gorbunova 1986); (9) Paykend, ca. 1100 AD (Mir-Makhamad et al. in review); (10) Barikot, ca 1200 BC (Spengler et al. 2020); (11) Semthan 1500-500 BC (Lone et al. 1993); (12) Gufkral and Bruzahon, ca. 1800-1000 BC (Kajale 1982); (13) Tarsus (Dioscorides 2000 [AD 64]); (14) Senuwar (ca. 2200-600 BC); (15) Jhusi (ca. 2200-1900 BC); (16) Chopani Mando (third millennium BC); (17) Koldihwa (third millennium BC); (18) Mahagara (early second millennium BC); 19) Bahola (second millennium BC); (20) Masudpur (second millennium BC); (21) Astana Cemetery, AD 304-439 (Chen et al. 2012); (22) Quseir al-Qadim, second century AD (van der Veen and Morales 2015); (23) Mishna (second century AD); (24) Lesbos (Theophrastus 1916 [350-287 BC]); (25) Rome (Apicius 1984 [first century AD]; (Pliny the Elder 1855 [AD 77-79]); Horace (2008 [35 BC]); (26) Kyung-lung Mesa, AD 455-700 (Song et al. 2018); (27) Zebang, first millennium AD (Song et al. 2018); (28) Amasya (Strabo 1924 [7 BC-AD 23]); (29) Agira (Diodorus 1967 [ca. 60 BC]); (30) Istanbul (Anthimus 1996 [AD 500-525]); (31) Babylonian Talmud (sixth century AD); (32) Aelia Mursa, early second century AD (Reed and Leleković 2019); (33) Novaesium, early first century AD (Knörzer 1970); (34) Mogontiacum, late first millennium AD (Zach 2002); (35) Teshik-Kala in Kharasam, between seventh and eighth century AD (Brite et al. 2017); (36) Erkala (Merv) probably from the third century AD (Usmanova 1963); (37) Mleiha in the United Arab Emirates, third century AD) (Dabrowski et al. 2021); (38) Bukhara, ca. 1000 AD, ongoing studies; (39) Afrasiab, ca. 1000 AD, ongoing studies; (40) Berenike, first centuries AD (Cappers 2006); (41) Myos Hormos, first centuries AD (van der Veen 2011)

Seteria viridis, and Acroptilon repens. Archaeological assessment of the mortuary goods left scholars uncertain as to the social status of the individual, but they estimated that the tomb dated between AD 327-460 ( $\mathrm{Li}$ and Zhang 2006). Bashtannik (2008) reported recovering two ancient rice grains, one from the fourth to fifth centuries AD at Karaspan-tobe and another from the seventh century $\mathrm{AD}$ at Djuvan-tobe. Both medieval village sites are located along a tributary of the Syr Darya on the arid southern rim of Kazakhstan. While Bashtannik's (2008) study was small, he did identify hundreds of grains of wheat, barley (Hordeum vulgare), and broomcorn millet (Panicum miliaceum), possibly suggesting that rice was still of minor significance in the early-medieval period. $\mathrm{He}$ also reported a small quantity of rice from the seventh century AD village of Konyr-tobe in the Otrar Oasis (Bashtannik 2008).

In the Semirech'ye region of southeastern Kazakhstan, a report of probable rice phytoliths in anthropogenic sediments was published from the sites of Tuzusai and Tseganka 8 (Rosen et al. 2000). The purported rice remains date to the mid- to late first millennium BC (Chang et al. 2002, 2003). Three seasons of additional archaeobotanical investigation at Tuzusai have failed to identify any macrobotanical remains of rice, calling into question the early claims (Spengler et al. 2017). Fan-shaped rice-like phytoliths were also reported from within sheep and goat dung from a desiccated 400 BC tomb in Xinjiang (Ghosh et al. 2008). The unlikeliness of rice at these high latitudes and in arid regions, especially 


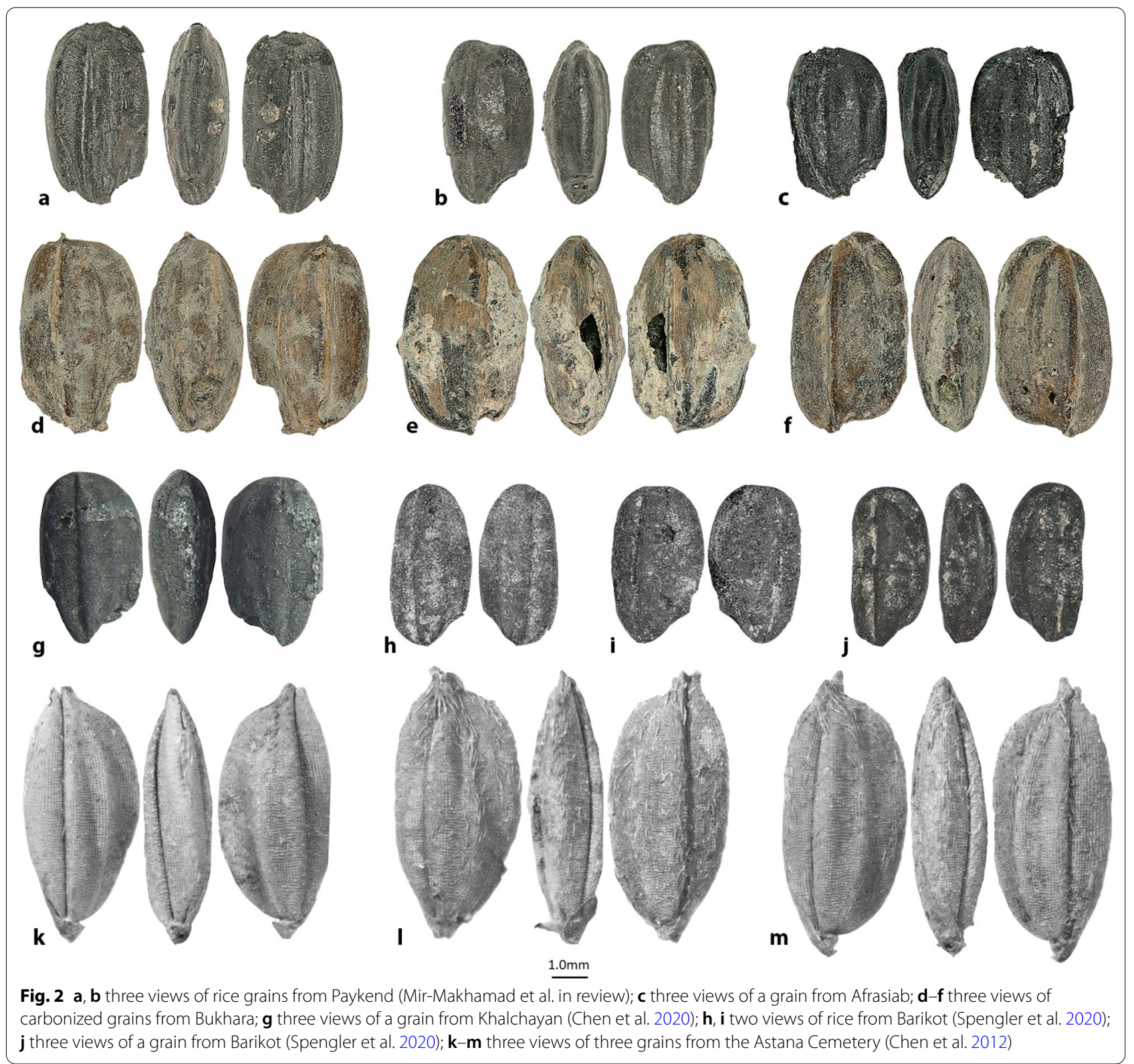

at this early period means that further research is needed either confirming or rejecting these reports, as with the above-mentioned early phytoliths from East and South Asia.

Other slightly later claims of archaeobotanical rice in Central Asia include a mention in an early Soviet excavation at Teshik Kala, Uzbekistan, in the Khorasam Oasis dating to the seventh or eighth century AD (Brite et al. 2017) and at Merv, Turkmenistan, from a Sasanian phase, slightly earlier than Teshik Kala (Usmanova 1963). The report of grains from Merv noted that they came from the mudbrick and plaster floor, but further substantiation of this claim is warranted. Three grains of rice were also recovered from a hearth in a rabat at Paykend, in the Bukhara Oasis of Uzbekistan, dating to the Qarakhanid period at roughly AD 1100 (Mir-Makhamad et al. in review; Fig. 2a, b). There are thousands of millet and cereal grains in the Paykend assemblage, illustrating the continued rarity of rice through the medieval period. Ongoing research at both Qarakhanid capital cities of Afrasiab and Bukhara have identified rice grains; although, again, in both cases comprising a few grains among tens of thousands of identified grains and legumes. A midden deposit in the residential area of Afrasiab-ancient Samarkand-led to the recovery of three rice grains (Fig. 2c), and excavations in an area near 
the Ark at the heart of ancient Bukhara has led to the recovery of more than one hundred rice gains (Fig. 2d, $\mathrm{e}, \mathrm{f})$, among tens of thousands of other economic seeds (Fig. 3).

\section{South Asian Coastal Routes}

\section{Historical Sources}

The Greek writer, Diodorus Siculus' Bibliotheca Historica (1967 [ca. 60 BC]: Book 2, Chapter 36), recapping accounts from now lost texts that supposedly dated several centuries earlier, mentioned rice being fed to soldiers of Eumenes of Cardia in 316 BC, presumably in the region of modern Iran. Additionally, Theophrastus (1916 [350-287 BC]: Book 4, Sect. 4) mentioned that rice was grown in India, a statement that indicates that he at least knew what rice was. It is likely that Theophrastus learned about the crop from members of Alexander's expedition, and he specified that it was consumed as a gruel or mash. Although, Bertoni (2014) suggests that Theophrastus was not directly familiar with the plant or its geographic origins, noting that the first time he mentions rice, he associates it with Egyptian varieties of wheat. Rice is mentioned in several Greco-Roman texts, but all of their authors would have had the Historia Planetarum to build upon. Interestingly, Strabo (1924 [7 BC-AD 23]: Book XV, Volume 1: 18) is credited with stating that rice was grown in Susis/Susiana, likely based on lost earlier accounts of Aristobulus of Cassandria (Dueck 2015). Of an even earlier date, perhaps also related to rice cultivation in Susiana, are two texts from the Persepolis Fortification Archive, seemingly mentioning the handling of rice (Elamite miriziš) at Liduma (499 BC) and Kurra (587 BC) - both places were situated on the Royal Road between Susa and Persepolis (Hallock 1969; Tavernier 2007; Muthukumaran 2014). These accounts may further be supported by the Shiji as well (Sima 1993 [109-91 BC]: Book 123), claiming that rice was grown in Anxi, which is thought to be an old Chinese term for the Parthian Empire. According to Laufer, even the negative evidence for West Asian rice consumption in Chinese annals carries weight, "since the Chinese as a rice-eating nation were always anxious to ascertain whether rice was grown and consumed by foreign peoples" (Laufer and Sino-Iranica 1919: 372). While most historians recognize that rice was present in West Asia by the tail end of the first millennium BC, it was likely a commodity crop (Laufer and Sino-Iranica 1919). Muthukumaran (2014) suggests that there may be even earlier Akkadian references to rice on cuneiform tables, but we will not explore those here.

Dioscorides (2000 [AD 64]) also mentioned the use of rice for making bread, which he states is less nourishing than wheat. In the Natural Histories, Pliny the Elder discussed a drink like "barley water" made from rice (Stadler 1914), although he also was not familiar with what the rice plant looks like, or is possibly describing a different plant: "Rice leaves are fleshy, resembling leek but

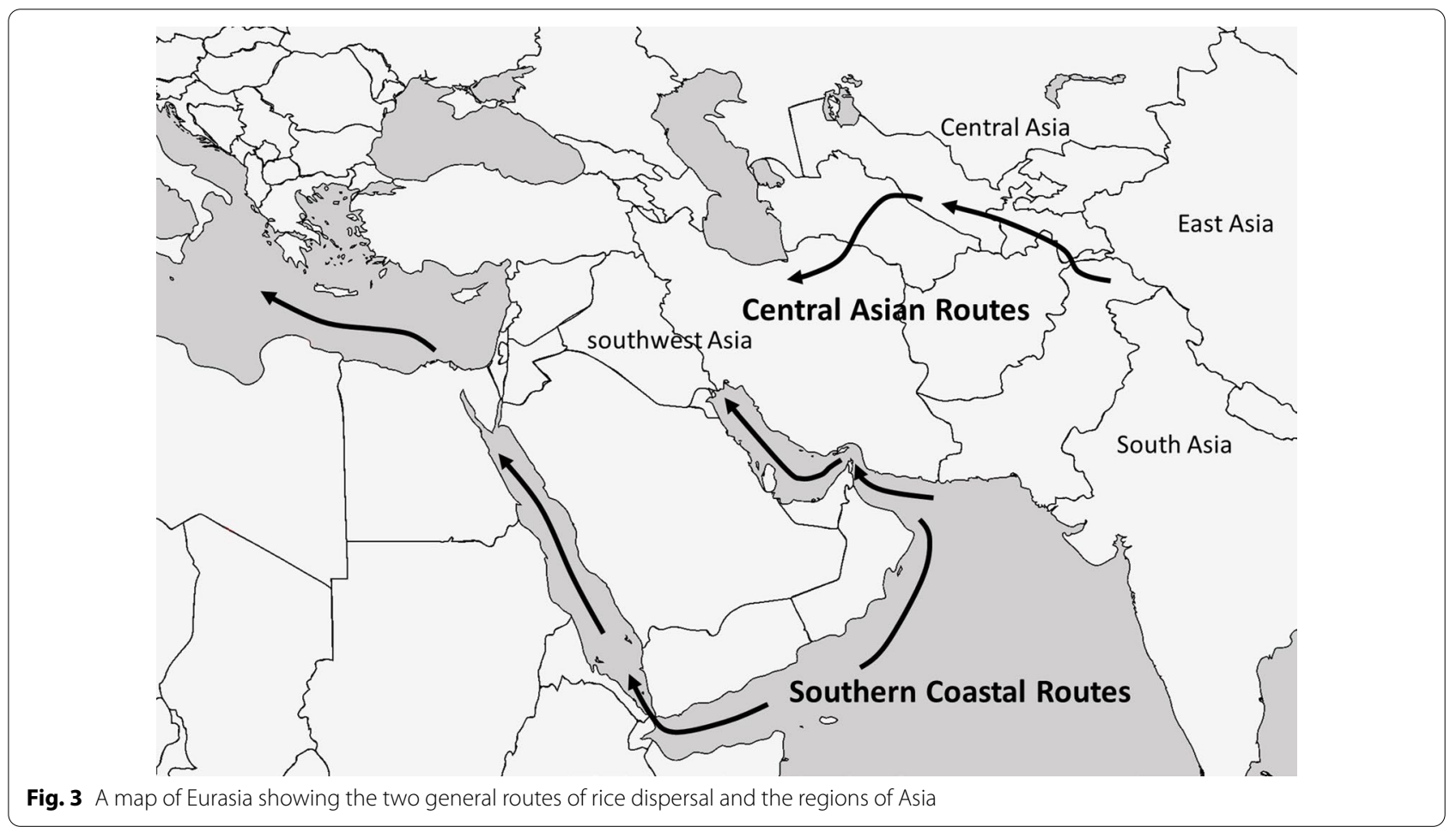


broader; the plant is 18 inches high, with a purple blossom and a root of a round shape like a precious stone" (1855 [AD 77-79]: Book 18, Chapter 13). Apicius, in his cookbook (1984 [first century AD]: Book 2, Chapter 2), claimed that rice was grown in West Asia; he specifically referred to it as a thickener for sauces. However, rice only appears in one percent of the 400 recipes in the book (Peterson 1980). Strabo (1924 [7 BC-AD 23]: Book 15, Chapter 1, Sect. 18), referencing earlier writings by Aristobulus, stated that "rice stands in enclosures of water, and it is included in beds". It is independently reported by Strabo and the Shiji (Book 123:3163) in reference to the country Tiaozhi, 條枝, probably the kingdom of Charakene around modern Basra, in the southern reaches of the Euphrates-Tigris River basin (Hill 2009; Yang 2014). Strabo also stated that rice was grown in Babylonia, Bactria, Susa, and lower Syria (Stadler 1914). Other Greco-Roman sources ascribe medicinal properties to rice (oryzae), including Horace's (2008 [35 BC]: Book 2, Chapter 3: 155) Satires and Celsus' (1938 [first century AD]: Book 2, Chapter 20:1) De Medicina. Celsus categorized the medicinal qualities of rice made into a gruel, with soft cheese, milk, nettle (Urtica dioica), mallow (Malva sp.), and raw eggs. Rice was mentioned in the early sixth century by the Byzantine physician, Anthimus (1996 [AD 500-525]) and by Galen (AD 150-210; Tassinari 2019), both of whom claim that rice porridge, made with goat milk, is good for an upset stomach. The medicinal use of rice to calm a stomach was widespread across the Mediterranean in the first millennium AD (Nesbitt et al. 2010). Classical references to rice as an Indian food, as a thickener for sauces, or as medicine, suggest that rice was a rare luxury ingredient in the Mediterranean during antiquity.

Rice was mentioned as a trade good in a logbook of Egyptian merchants on the Red Sea in the first century AD, in the Periplus Maris Erythraei (Schoff 1912). Both historical and archaeobotanical references to the grain at Red Sea ports in Egypt seem to suggest that it may have been an elite exchange good transported by nautical merchants. Other scholars have also emphasized the likelihood of rice being traded through the Red to the Mediterranean Sea as a commodity good. The weight of grain and the friction of overland travel may explain why it took so long to disperse across much of West Asia. As many scholars have pointed out, the cost of transporting grain over land in the ancient world was prohibitively expensive. Decker (2009) writes that rice became established as a local crop in Egypt by the second century AD. However, Cappers (2006) notes that there are only four reported references to rice out of 34,230 ancient papyrus texts of the third century $\mathrm{BC}$ to the eighth century AD. Early references to what is likely rice in the southern
Levant appear in ancient Biblical translations by the first centuries AD, including the Samaritan Aramaic Targum, the Greek Samariticon and the Syriac Peshitta (Löw 1924; Feliks 1963; Rabin 1966). Judeans and Samaritans probably first encountered rice as a luxury import, and one scholar has proposed the Biblical 'wheat of Minnith' (Ezekiel 27:17), which refers to a luxury export from Judea to Tyre, was rice (Rabin 1966). Definitive references to rice (orez) as a local food crop appear in the Mishna, the classic second century $\mathrm{AD}$ rabbinic text (reflecting realia of the first centuries $B C$ and $A D)$.

The rabbinic references suggest that rice was well known in the southern Levant by this time but was not long-established (Feliks 1963). The Mishna distinguishes between rice grown within and outside the Land of Israel (Mishna, Demai 2:1), while related rabbinic sources refer to red rice grown on the plain of Antioch as distinct from Israel's white rice (Tosefta, Demai 2:1; Jerusalem Talmud, Demai 2:1 - summarized in Feliks 2008). Other references in rabbinic texts suggest that rice was: (1) cultivated as a summer crop in Roman Palestine; (2) exported to neighboring regions; (3) stored husked or de-husked; and (4) roasted, baked, or boiled (Mishna, Shevi'it 2:7, 10; Hallah 1:4, 3:7, 10, 4:3; Pe'ah 8:3-summarized in Feliks 1963, 2008). References in the Jerusalem Talmud (redacted late fourth to early fifth century AD) and the Rehov inscription, suggest that local cultivation continued in early Byzantine Palestine. As elsewhere, rice in ancient Palestine was grown in those regions in which year-round irrigation was possible, such as Paneas, the Sea of Galilee, the upper Jordan Valley, and the Bet Shean Valley (Feliks 1963; 2008; Amar 2000; Safrai 1994). References to rice in the Babylonian Talmud, compiled in Mesopotamia (redacted fifth to sixth centuries AD, with additional editing until the early seventh century) indicate cultivation in Sasanian Iraq. These and other historical sources attest to rice cultivation in different parts of the Sassanid and Byzantine empires of Late Antiquity before the Islamization of both (Decker 2009).

Historians have suggested that rice cultivation expanded in the early Islamic period (Ashtor 1975 [1969]; Watson 1983; Amar 2000). One early Islamic testimony for the cultivation of rice outside of Khuzestan (west of the southern Euphrates-Tigris basin) comes from the physician 'Alī b. Sahl Rabbān al-Ṭabarì (not to be confused with the historian, see below) in his Firdaws al-hikmah fi al-tibb (finished in AD 850), stating: "I saw rice in Tabaristān, which was 40 years old" (al-Tabarī 1928: 375). There are, however, indications that the cultivation of rice gained importance in Ērānshahr (in the Iranian heartland of the Sasanian Empire) during the Late Sasanian period. Perhaps best known in this respect is rice mentioned as one of the crops on which the land 
tax was based following the tax reforms of Khusraw I with a tax rate of five-sixths of a dirham per jarib (ca. 1,600 square meters) of rice (al-Dīnawarī 1912: 72-73; al-Ṭabarī 1928: 962). In the region around Basra, cultivation of rice is attested for the period of the Arab expansion, ca. AD 630 (Ibn al-Faqih 1885: 187). It is the often overlooked in Rashīd al-Dīn's Kitāb-i äthār wa ahya ${ }^{\prime}$ that rice was mentioned during the Late Sasanian Period in Iran by Khusraw I Anūshirwān (Rashīd al-Dīn 1989; Petrushevskii 1960). Additionally, at the Late Sasanian court, rice and rice products were not only served (al-Tha'âlibì 1900: 585), but also played a role in Nawrūz rituals around the eleventh century, as noted in the Kitāb al-mahāsin wa'l-addād (1898; Ehrlich 1930)-likely the late ninth century author, Abū al-Ḥusayn 'Alī ibn Mahdī al-Kisrawī, who wrote a Book on Feasts and Nawrüzes (Ibn al-Nadim 1871-1872).

In the late tenth century, al-Muqaddasi mentioned rice cultivation for export in the Bet Shean Valley, and at least one text suggests that exportation of rice from Palestine continued in the thirteenth century (Amar 2000). Meanwhile, rice cultivation apparently expanded in Egypt, and became the chief staple cereal in the Fayyum (Ashtor 1975 [1969] quoting al-Muqaddasī and Ibn Haukal). In Mamluk Palestine (mid-thirteenth to early sixteenth centuries), local rice production was taxed (Amar 2000:75). It remained a minor crop, in relation to wheat and barley, and its appearance in medieval Arabic cookbooks is usually as a component of luxury dishes (Ashtor 1975 [1969]). According to Amar (2000), rice production declined in Palestine during the Ottoman period. Indeed, in the eighteenth century elite Ottoman Court, rice was apparently an imported commodity, mostly arriving from Egypt and reserved for banquets (Grehan 2007). Rice appears only to have become a widespread dietary staple throughout the Levant during the twentieth century.

As we elaborate upon below, rice remains elusive in archaeobotanical studies from West Asia and Europe, but it is found scattered across this vast region by the first millennium AD. Persian, Roman, and early Islamic irrigation infrastructure apparently facilitated expansion of cultivation, but its cultivation appears to have remained restricted to wetter microregions. As a result, rice remained a luxury food in West Asia and the Mediterranean.

\section{Archaeobotanical Data}

Archaeobotanically, rice is rare in Central and southwest Asia, often appearing as one or two grains among thousands of domesticated crop remains at sites dating to the medieval period and later. Rice grains were recovered from a Parthian (ca 250 BC-AD 230) context at Susa, Iran-the same ancient city noted by Strabo (1924 [7
BC-AD23]) for rice cultivation. Miller (1981) noted 373 carbonized seeds of a short-grained variety of rice on the floor of Level 3A at Ville Royale II, in association with a jar that was likely a storage container for the grains, possibly as an offering. As with many of the historical sources, the context of this discovery, in a palace, suggests that rice may have originally been an elite commodity in West Asia. Impressions of rice husks in mudbricks were reported at sites in the South Dez plain near Susa, dating between $25 \mathrm{BC}$ and $\mathrm{AD} 250$; if these impressions are accurately identified, they might suggest local cultivation rather than import, but scholars are hesitant to accept the claims (Nesbitt et al 2010; Miller 2011). Preserved carbonized grains of rice were found in low abundance at the second century AD ( $n=33$ grains) Roman trading port of Quseir al-Qadim in Egypt, and a few grains were recovered from the Roman trading centers of Berenike and Myos Hormos (Cappers 2006; van der Veen 2011; Fig. 1). The grains at Quseir al-Qadim were mainly found in contexts near the port and found in association with mung bean (Vigna radiata) and coconut shell (Cocos nucifera) (van der Veen and Morales 2015). At both Red Sea coastal sites, rice grains were found in later stratigraphic layers, but remain at low abundance through the Islamic period. Scholars have argued that rice was imported to the region during the Roman period but may have been locally cultivated on a small scale during the Islamic period (van der Veen and Morales 2015; van der Veen et al. 2018). Another recent discovery of archaeobotanical remains of rice further supports a southern coastal route of dispersal; a fortified elite residence at the site of Mleiha in the United Arab Emirates was partially destroyed by a fire in the third century AD (Dabrowski et al. 2021). Carbonized rice grains at the site attest to its preparation as food and the processing of the husk from the grain, but the excavators still consider it a rare crop overall. Rice was recovered from three different rooms in the complex, as well as in the courtyard, and many of the grains were recovered in adhered clusters.

Much further afield, five rice grains were found in association with black pepper (Piper nigrum) from a series of trash pits filled with domestic waste dating to the early second century AD, near the center of the colonia Aelia Mursa in Croatia (Reed and Leleković 2019). The floated sediments constituted $850 \mathrm{~L}$ and were rich in grains and legumes that were likely locally grown, with rice and peppers presumably representing rare imports. Additionally, 196 charred grains of rice were recovered from the Roman military encampment or fort of Novaesium along the Rhine River, from the early first century AD, near the modern city of Düsseldorf (Knörzer 1966, 1970). The architectural structure where the grains were recovered has been interpreted by the archaeologists as a military 
medical facility, supporting the argument that rice in the Roman world served a medicinal role. A single probable rice grain was also recovered from the late first millennium AD from among sacrificial offerings at the Temple of Isis and Magna Mater in the Roman city of Mogontiacum, the capital of Germania Superior, where Mainz is today (Zach 2002). The scattered archaeobotanical remains of rice in West Asia and Europe support the view that rice was an exotic import in the Roman Empire and that in addition to medicine, it was an elite commodity for special meals (Zaouali 2009; Marton 2014; van der Veen and Morales 2015).

\section{Intensification of Rice Cultivation}

Farmers around the world have engaged in increasingly intensive rice cultivation practices, even in the face of some of the least arable ecological conditions. The intensification of an extremely water-demanding crop in the arid regions of West Asia is testament to the ingenuity of ancient populations and illustrates that decisionmaking is often driven by cultural factors, such as taste and cuisine. Standing-water rice cultivation in most areas of West Asia is extremely labor intensive, it can lead to increased soil salinity, and is often at high risk for crop failure. Cultivation often requires regular drainage and re-irrigation of plots to avoid salt accumulation (Samuel 2001). The practice of regular water circulation is ethnohistorically attested in Afghanistan and Syria, where rice fields were also kept small and left fallow for threeyear periods (Samuel 2001). Archaeobotanical and early historical evidence suggests that rice cultivation in West Asia was restricted to particularly rich and well-watered ecotopes and specifically for elite consumption until the late medieval period. In fact, Bacon (1980) suggested that in the recent past only the richest members of society could afford to make their pilaf out of rice (as opposed to barley).

Rice gradually increased in culinary significance across South Asia. Several millennia before rice became important in West Asia, barley was the most abundant grain at Hetapatti, but at later sites on the Ganges Plain, rice is more abundant (Pokharia et al. 2017). By the late first millennium $\mathrm{BC}$, at the site of Rajdhani, rice grains were 250 times more abundant than barley grains, seemingly illustrating a major shift in cultivation practices over time. Pokharia et al. (2017) point out that all other cultivated crops in the Rajdhani assemblage combined, represent only about four percent of the overall cultivated crops, with rice significantly dominating the assemblage. In most South Asian archaeobotanical assemblages, rice is only one of a number of different crops, but it likely played an important role as a summer crop in seasonal rotation systems.
The prominence of rice cultivation around the world today is tied into crop-rotation cycles. Arguably, croprotation cycles are referenced in Chinese texts as far back as The Book of Songs (770-476 BC; Guo 1982); although, texts from the Han Dynasty, such as The Book of Sisheng, suggest a cycle of winter wheat and short-season millet was prominent. By the mid-first millennium AD, it is clear that these farming systems had been significantly intensified, with regionally specific forms of rotation (Guo 1982). During the Han Dynasty, collective labor projects involving irrigation expanded across northern China and spread into arid western China (Zhang and Tian 2015; Li et al. 2017). The demographic shift that marks the onset of the Han Dynasty, is likely tied into crop-rotation cycles and the expansion of summerirrigated fields (Hosner et al. 2016). Archaeobotanically, the increased prominence of wheat in northern China starts to show up as early as 1000 BC (Deng et al. 2020) but really takes over in the Han Dynasty, which coincides with the culinary shift toward grinding and the use of noodles and steamed buns (Bray 1984). While multicropping systems of winter wheat and summer millet were practiced as far back as the first century $\mathrm{BC}$, attested in Fan Sheg-Chih's agricultural manual (Shih 1959), a croprotation cycle utilizing rice was not possible before the development of the rapid-maturing varieties.

Prior to the Song Dynasty in China, most rice was likely cultivated as a summer crop near natural water sources or on easily flooded land. Due to the long cultivation season of these early rice varieties, only one annual crop rotation would have been feasible and rice would have occupied the most arable land. Scholars have suggested that the intensification of rice cultivation in East Asia was tied into the development of a variety of rice with a shorter growing season (Ding 1957; Chang 1976; Anderson 1988; Simoons 1990). The rapid-growing Champa rice spread into the Yangtze River from Fujian in the eleventh century; historical sources specifically claim that it was introduced by Emperor Chang-tsung in 1011 (Anderson 1988, 2014). Large-scale collective labor projects, including irrigation, dam and levee construction, and forest clearing supposedly occurred in the Song period, accompanying the introduction of doublecrop systems in southern China (Anderson 2014). The resulting demographic increase in East Asia would mirror the agricultural demographic transition in the north, with wheat/millet rotation cycles starting in the Han Dynasty, or the East-Asian-wide demographic transition that resulted from the introduction of Green Revolution crops and male-sterile hybrid rice in the 1960s.

Laufer and Sino-Iranica (1919) believed that rice cultivation in West Asia was not a prominent activity until the beginning of the Islamic period (after the seventh 
century AD). Watson (1983: 17) echoed these views, claiming that in "the eastern part of the caliphate, where rice had been grown in ancient times, and the early centuries of Islam saw an extension of its cultivation". He further argued (1983: 17) that "rice early came to be grown in the Islamic world almost wherever there was water enough to irrigate it". Watson directly tied the importance of rice in West Asian cuisines to the Islamic Expansion (starting in AD 623), as a fixture of his Early Islamic agricultural revolution. While many scholars have disputed aspects of Watson's claims (Johns 1984), other scholars have broken down his claims, noting that the archaeological and historical records are not clear and all corollary factors for the intensification of farming have not been explored-likely much but not all of Watson's thesis is true (Decker 2009; Fuks et al. 2020; Kennedy 2011; Squatriti 2014). Archaeobotanical studies in southwest Asia from Islamic periods are lacking, due to a focus on earlier periods. However, Samuel (2001) reports plant remains from a few village sites along the upper and middle Euphrates River. She did not recover any rice from contexts dating between the eighth and tenth centuries, but she did report a small amount of carbonized grains and rachis bases from eleventh through fourteenth century layers.

Arab geographers, such as al-Muqaddasi (AD 945991), noted government-sponsored irrigation projects, specifically in this case along the Kur River of the Fars Region of Iran. Al-Muqaddasi also claimed that the ancient city of Istakhr, on the Pulvar River, a tributary of the Kur, was surrounded by rice fields and fruit orchards (Sumner and Whitcomb 1999). Rashidal-Din Hamadani (1247-1318), a political figure and historian during the Ilkhanate, described a variety of rice that was popular in India that resembles Basmati (Anderson 2014). In the Memoirs of Babur, the ruler noted that, as his armies moved through the hills of the Kafiristan region of Afghanistan, the Kafir people fled or were killed, and his troops seized large quantities of rice (Babur 1922 [1483-1530]: Volume 2, Chapter 14). Abu'l-Fazl ibn Mubarak, the vizier to the sixteenth century emperor, Akbar, recorded recipes for preparing rice (Fazl 1873-1907 [1597]: Volume 1, Chapter 49-55). The Arabic geographer, al-Muqaddasi (945-991) discussed dams and irrigation systems to water rice fields and orchards, built around the lower Kur River near ancient Istakhr in Iran. The Mughal Emperor, Nuruddin Muhammad Jahangir (1569-1627) references the cultivation of rice in the Samarkand region (Jahangir 1909-1914 [1569-1627]). As a final point, there are some references to more arid-tolerant ancient forms of rice; for example, a specific form of dry-land and salttolerant rice may have been introduced to the southern
Arabian Peninsula from India along the Red Sea trade routes, possibly linked to historic cultivation of Hassawi Rice (Dabrowski et al. 2021).

\section{Culinary Shift}

Fuller and Rowlands (2011) note that a long lasting culinary divide has bisected Asia, with baking and grinding cuisines to the west and steaming and boiling cuisines to the east. In their discussion of this divide they focus on the culinary role of grain crops as they dispersed across Asia. Notably, millets are used to produce savory porridges in East Asia and in at least a few ancient examples are transformed into hard unleavened breads in West Asia. Similarly, wheat transforms into steamed buns, noodles, and dumplings in East Asia, as opposed to the baked breads of West Asia. The westward dispersal of rice appears to have resulted in a similar transformation. While Classical European texts refer to rice as an exotic (e.g. Theophrastus 1916 [350-287 BC]), largely medicinal plant (e.g. Anthimus; Celsus; Galen; and Horace), in cases where culinary properties are discussed, they refer to the use of rice water or ground flour. Classical writers also discuss the use of rice to make drinks, likely fermented, and bread. Feliks (1963) identifies sweet dishes of rice mixed with fruits and wine in Talmudic sources of the fifth to seventh centuries. Other historical references are made to a jelly-like dish or sweet porridge and sweet cakes (Nesbitt et al. 2010).

Even in early Arabic references to the culinary uses of rice, authors do not discuss dishes similar to pilaf; rather, they talk about rice beer, baked breads or pastries made from rice flour, and sweetened porridge with milk. The culinary use of rice in Turkic and Arabic cuisines appears to be a recent cultural adoption, possibly accompanying the wider cultivation of rice over the past few hundred years. Rice pilaf may be a recent adaptation of a boiled or fried barley dish that loosely shared many of the same properties (Bacon 1980). The earliest of the early Arabic cookbooks, dating somewhere between AD 940 and 960, included 615 recipes pulled together by Sayyar al-Warraq (Nesbitt et al. 2010; Nasrallah 2007; Marton 2014). Only a few of these recipes involve rice, notably in the form of rice bread and fermented beer. Nesbitt et al. (2010) note that, of the four early Arabic cookbooks dating to the thirteenth century, the ones written later in time have more recipes for rice. They also note that many of the recipes were for porridges, sometimes with meat, but often with sugar or honey, and in many of the dishes small quantities of rice, sometimes as flour, are used as a thickener. Samuel (2001) also references historical texts from the ninth and tenth centuries that mention sweet rice and milk porridges, with fruit syrups, saffron, sugar, grapes, figs, dates, or honey, and instructions for 
fermenting the grains or baking with rice flour. As the culinary role of rice changed, its prominence in West Asian cuisine increased.

Another preserved Arabic cookbook, the Kitab alTabikh, written by Muhammad bin Hasan al-Baghdadi in 1226, references several dishes with rice (Perry 2017). One thirteenth century cookbook presents nine dishes that contain rice, mostly pilafs; however, overall, rice is a minor component, and the Book of Scents and Flavors the Banqueter Favors was clearly written for an elite palate (Perry 2017). Another of these cookbooks, the Kitab al-Wusla written by Ibn al-Adim of Aleppo, who lived in Gaza and Egypt, and wrote the book in the early thirteenth century, provides the first clear reference to a pilaf-like dish, with rice, garlic, meat, and chickpeas (Nesbitt et al. 2010; Zaouali 2009). Nasrallah (2018) recently translated another Egyptian cookbook, Treasure Trove of Benefits and Varieties at the Table, which date to the fourteenth century and has additional recipes for rice, illustrating a gradually increasing culinary importance. Watson (1983) compared the number of recipes with rice to the number of ways to produce pickles, noting that the author presents dozens of ways to make pickled vegetables. Several early Arabic geographers or travelers also mention rice; Ibn Battuta (1325-1354) mentions consuming rice bread while on his trip from Mecca to Medina. Ibn Fadlan (2012 [921]) repeatedly references a dish of rice and fish. Chang Chun (1888 [1228]) mentioned rice growing in the Amu Darya river basin, presumably along the modern borders of Uzbekistan and Turkmenistan. The number of references to savory rice dishes with meat increases over time. Several scholars have pointed out that many of the customs associated with making pilaf, such as washing the rice, are evident in these early cookbooks (Zaouali 2009; Nesbitt et al. 2010; Marton 2014). Rice became prominent in the wet river valleys across West Asia before the first European explorers reached the region, by which time pilaf-like dishes were already popular. For example, Burnes (1834: Book 1: 228) references a rice and meat dish in Bukhara. Mac Gahan (1876: 318) mentions eating pilaf while traveling along the Amu Darya; Marvin (1881) describes pilaf in Merv; Schuyler (1877: 125) describes it in Turkmenistan.

\section{Conclusions}

The gradual transition from a wild to a domesticated population of rice in the lower Yangtze basin, as is archaeobotanically visible at the sites of Tianluoshan and Hemudu, culminated around $4600 \mathrm{BC}$. This first anthropogenic trait of domestication became fixed into a cultivated population in East Asia, and from there spread into South Asia, likely through rich mountain passes. The allele for tough rachises introgressed into South
Asian rice representing domestication. The transfer of the allele from fully domesticated japonica rice to previously wild indica rice ultimately resulted in separate basmati and pearl rice clades. It is rather clear from the historical and archaeobotancial data that rice dispersed along two routes on its journey to the west. One of these routes crossed the deserts of southern Central and southwest Asia and the other traversed the coast through nautical routes from India and up the Red Sea to the Mediterranean.

Rice gradually increased in culinary significance across South Asia and eventually spread into Central and arid southwest Asia to become a prominent grain by the late medieval or early modern period. Much remains to be discovered regarding the precise timing of this westward dispersal and the extent to which greater irrigation and public-works projects were tied into the increased prominence of the crop through time. However, the earliest culinary role for rice in West Asia was in sweet porridges and as medicine; its savory staple role developed later. Archaeobotanical data in the southern Himalaya does not stretch back far enough, but the presence of rice cultivation in these rich river valleys supports the likelihood of a dispersal along this route. While rice is an important part of Central Asian cuisines, it probably did not become a significant crop west of the Indus region until well after the Islamic Expansion. The pilaf or other ricebased dish that exemplifies many Central and southwest Asian cuisines probably only originated over the past millennium.

\section{Authors' Contributions}

RNS designed and organized the project, all other authors contributed equally.

Funding

Open Access funding enabled and organized by Projekt DEAL. Research funds and support were provided by the Max Planck Institute for the Science of Human History and the European Research Council, grant number 851102, Fruits of Eurasia: Domestication and Dispersal (FEDD), and the NSFC (41672171).

Availability of Data and Material

All discussed data is presented in the text of figures.

\section{Declarations}

Ethics Approval and Consent to Participate Not applicable.

Consent for Publication

Not applicable.

Competing Interests

The authors declare that they have no competing interests.

\section{Author details}

${ }^{1}$ Department of Archaeology, Max Planck Institute for the Science of Human History, Jena, Thuringia, Germany. ${ }^{2}$ Institute for the Study of the Ancient World, New York University, New York City, NY, USA. ${ }^{3}$ Key Laboratory of Vertebrate 
Evolution and Human Origins, Institute of Vertebrate Paleontology and Paleoanthropology, Chinese Academy of Sciences, Beijing, China. ${ }^{4}$ Department of Archaeology and Anthropology, University of Chinese Academy of Sciences, Beijing, China. ${ }^{5}$ Center for Excellence in Life and Paleoenvironment, Chinese Academy of Sciences, Beijing, China. ${ }^{6}$ McDonald Institute for Archaeological Research, University of Cambridge, Department of Archaeology, Cambridge, UK. ${ }^{7}$ Martin (Szusz) Department of Land of Israel Studies and Archaeology, BarIlan University, Ramat Gan, Israel. ${ }^{8}$ Dipartimento di Studi sull'Asia e sull'Africa Mediterranea, Università Ca' Foscari Venezia, Venice, Italy. ${ }^{9}$ ISMEO - International Association for Mediterranean and Oriental Studies, Rome, Italy. ${ }^{10}$ BerlinBrandenburg Academy of Sciences and Humanities, Turfanforschung, Berlin, Germany. ${ }^{11}$ Department of Anthropology, Smithsonian Institution, National Museum of Natural History, Washington, DC, USA. ${ }^{12}$ School of Social Science, The University of Queensland, Brisbane, Australia. ${ }^{13}$ Department of Anthropology and Archaeology, University of Calgary, Calgary, Canada.

Received: 4 February 2021 Accepted: 5 August 2021 Published online: 25 September 2021

\section{References}

Agostini D, Stark S (2016) Zāwulistān, Kāwulistān, and the Land Bosi. On the question of a Sasanian court-in-exile in the southern Hindukush. Stud Iran 45:17-38. https://doi.org/10.1163/9789004378391009

Aldenderfer MS, Olsen JW (2008) Archaeological Research Conducted in Ngari Prefecture, Tibet Autonomous Region and in the Amdo Region, Qinghai in 2007. Report of Field Investigations, On File. Dept. Anthro., U. Arizona.

al-Dīnawarī, Abū Ḥanîfah Aḥmad ibn Dāwūd (1912) Kitāb Al-Akhbār Al-Ṭiwāl. Ignatij Julianovič Kračkovskij (ed). Brill, Leiden

al-Muqaddasī (1886) Description of syria including palestine, trans. Guy Le Strange. Palestine Pilgrim's Text Society, London

Alram M (2016) Das Antlitz des Fremden. Die Münzprägung der Hunnen und Westtürken in Zentralasien und Indien. Verlag der Österreichischen Akademie der Wissenschaften, Wien

al-Ṭabarī “Alī ibn Sahl Rabbān (1928) Firdaws al-ḥikmah fĩ al-țibb, ed. M. Z. Siddiqi (=Firdausu'l-Hikmat or Paradise of Wisdom). Berlin-Charlottenburg: Buch-und Kunstdruckerei "Sonne."

al-Tha 'ālibī 'Abd-al-Malik Ibn-Muhammad (1900) Ghurar akhbār mulūk al-furs wa-siyarihim, ed. and transl. H. Zotenberg (=Histoire des rois-des Perses, par Aboû Mansoûr 'Abd al-Malik Ibn Mohammad Ibn Ismā ‘îl Al-Tha'âlibî). Paris: Imprimerie national, p758

Amar Z (2000) Agricultural produce in the land of Israel in the middle ages (Hebrew), Jerusalem

Ammerman AJ, Cavalli-Sforza LA (1984) The Neolithic transition and the genetics of populations in Europe. Princeton University Press, Princeton

Anderson EN (1988) The food of China. Yale University Press, New Haven

Anderson EN (2014) Food and environment in early and medieval China. University of Pennsylvania Press, Pennsylvania

Anthimus (1996 [A.D. 500-525]) On the Observance of Foods, translated by Mark Grant. Prospect Books, London

Apicius (1984 [first century A.D.]) The Roman cookery of apicius. Trans. John Edwards. Hartley \& Marks, Vancouver

Ashtor E (1975 [1969]) An essay on the diet of the various classes in the medieval Levant. In: Forster R, Ranum O (eds), Biology of Man in history: selections from the Annales Economies, Societies, Civilisations. P. Ranum (trans.), pp 125-162

Bābur (1922 [1483-1530]) The Bābur-nāma in English (Memoirs of Bābur). Luzac \& Co. London

Bacon EE (1980) Central Asia under Russian rule: a study in culture change. Cornell University Press, New York

Bailey HW (1979) Dictionary of Khotan Saka. Cambridge University Press, Cambridge

Bandey AA (2009) Prehistoric Kashmir: archaeological history of Palaeolithic and Neolithic cultures. Dilpreet Publishing House, New Delhi

Bashtannik S (2008) Археоботанические исследования на средневековых памятниках долины реки Арысь (Archaeobotanical research in medieval sites in the Arys river valley). Bull Archaeol Anthropol Ethnogr 1:85-92

Bates J, Petrie CA (2016) Phytolith analysis and the indus civilisation: a review. Man Environ 41:32-49. https://doi.org/10.17863/CAM.10163
Bates J, Petrie CA, Singh RN (2016) Approaching rice domestication in South Asia: new evidence from Indus settlements in northern India. J Archaeol Sci 78:193-201. https://doi.org/10.1016/j.jas.2016.04.018

Bates J, Singh RN, Petrie CA (2017a) Exploring Indus crop processing: combining phytolith and macrobotanical analyses to consider the organisation of agriculture in northwest India c. 3200-1500 bc. Veg Hist Archaeobot 26:25-41. https://doi.org/10.1007/s00334-016-0576-9

Bates J, Petrie CA, Singh RN (2017b) Cereals, calories and change: exploring approaches to quantification in Indus archaeobotany. Archaeol Anthropol Sci 10:1703-1716. https://doi.org/10.1007/s12520-017-0489-2

Battuta I (2014) Travels in Asia and Africa: 1325-1354. Routledge, London

Benveniste E (1940) Textes sogdiens (Mission Pelliot, III). Librairie Orientaliste Paul Geuthner, Paris

Bertoni DR (2014) The cultivation and conceptualization of exotic plants in the Greek and Roman Worlds. Doctoral dissertation. Harvard University, Cambridge

Betts A, Yatoo M, Spate M et al (2019) The Northern Neolithic of the Western Himalayas: new research in the Kashmir Valley. Archaeol Res Asia. https://doi.org/10.1016/j.ara.2019.02.001

Bocquet-Appel J-P (2011) When the World's Population Took Off: The Springboard of the Neolithic Demographic Transition 333:560-561. https:// doi.org/10.1126/science.1208880

Bogolyubov M and Smirnova O (1963) Согдийские документы с горы Муг. Хозяйственные документы (Sogdian documents from Mount Mog. Economic documents) Выпуск 3 (Volume 3). Moscow: Издательство восточной литературы (Publishing House of Oriental Literature)

Boivin N, Fuller DQ, Crowther A (2012) Old World globalization and the Columbian exchange: comparison and contrast. World Archaeol 44:452-469. https://doi.org/10.1080/00438243.2012.729404

Boyce M (1979) Zoroastrians: their religious beliefs and practices. Routledge \& Kegan Paul, Boston

Brace S, Diekmann Y, Booth TJ et al (2019) Ancient genomes indicate population replacement in Early Neolithic Britain. Nat Ecol Evol 3:765-771. https://doi.org/10.1038/s41559-019-0871-9

Bray F (1984) Science and Civilization in China. Vol 6, Part Il: agriculture. Cambridge University Press, Cambridge.

Brite EB, Khozhaniyazov G, Marston JM et al (2017) Kara-tepe, Karakalpakstan: Agropastoralism in a Central Eurasian Oasis in the 4th/5th century A.D. Transition J F Archaeol 42:514-529. https://doi.org/10.1080/00934690. 2017.1365563

Brykina GA (1974) Карабулак (Karabulak). Наука (Nauka), Moscow

Burnes A (1834) Travels into Bokhara: Beginning the account of a journey from India to Cabool, Tartary, and Persia. John Murray, London

Cappers RTJ (2006) Roman Foodprints at Berenike: Archaeobotanical Evidence of Subsistence and Trade in the Eastern Desert of Egypt. Cotsen Institute of Archaeology Press at UCLA, Los Angeles

Castillo CC, Tanaka K, Sato Yl et al (2016) Archaeogenetic study of prehistoric rice remains from Thailand and India: evidence of early japonica in South and Southeast Asia. Archaeol Anthropol Sci 8:523-543. https:// doi.org/10.1007/s12520-015-0236-5

Chang C (1888 [1228]) The Travels To the West of Kiu Ch'ang Ch'un, 1220-1223. In Medieval Researches from Eastern Asiatic Sources, Volume 1. Emil Bretschneider (Trans.), London: Trubner \& Co

Chang TT (1976) Rice. In: Simmonds NW (ed) Evolution of Crop Plants. Longman, London, pp 98-104

Chang C, Tourtellotte P, Baipakov KM and Grigoriev FP (2002) The Evolution of Steppe Communities from Bronze Age through Medieval Periods in Southeastern Kazakhstan (Zhetysu). Sweet Briar College, Sweet Briar, Virginia

Chang C, Benecke N, Grigoriev FP et al (2003) Iron age society and chronology in South-east Kazakhstan. Antiquity 77:298-312. https://doi.org/10. 1017/S0003598X00092280

Chantraine P (1968) Dictionaire Étymologique de la Langue Grecque. Klincksieck.

Chen T, Wu Y, Zhang Y et al (2012) Archaeobotanical study of ancient food and cereal remains at the astana cemeteries, Xinjiang, China. PLoS ONE 7:1-9. https://doi.org/10.1371/journal.pone.0045137

Chen G, Zhou X, Wang J et al (2020) Kushan Period rice in the Amu Darya Basin: evidence for prehistoric exchange along the southern Himalaya. Sci China Earth Sci. https://doi.org/10.1007/s11430-019-9585-2 
Civán P, Craig H, Cox CJ, Brown TA (2015) Three geographically separate domestications of Asian rice. Nat Plants 1:1-5. https://doi.org/10.1038/ nplants.2015.164

Cobo JM, Fort J, Isern N (2019) The spread of domesticated rice in eastern and southeastern Asia was mainly demic. J Archaeol Sci 101:123-130. https://doi.org/10.1016/j.jas.2018.12.001

Coningham RAE and Young RL (2015) The Archaeology of South Asia: From the Indus to Asoka C.6500 BCE-200 CE. Cambridge University Press, Cambridge

Costantini L (1987) Appendix B. Vegetal remains. In: Stacul G (ed) Prehistoric and Protohistoric Swat, Pakistan. Instituto Italiano per il Medio ed Estremo Orientale, Rome, pp 155-165

d'Alpoim Guedes J, Jiang M, He K et al (2013) Site of Baodun yields earliest evidence for the spread of rice and foxtail millet agriculture to southwest China. Antiquity 87:758-771. https://doi.org/10.1017/s0003598x0 0049449

Dabrowski V, Bouchaud C, Tengberg M, Mouton M (2021) Crop processing, consumption and trade of Asian rice (Oryza sativa L.) in the Arabian Peninsula during Antiquity: earliest evidence from Mleiha (third c. AD), United Arab Emirates. Archaeol Anthropol Sci. https://doi.org/10.1007/ s12520-021-01277-5

Dal Martello R, Min R, Stevens C et al (2018) Early agriculture at the crossroads of China and Southeast Asia: Archaeobotanical evidence and radiocarbon dates from Baiyangcun, Yunnan. J Archaeol Sci Reports 20:711-721. https://doi.org/10.1016/j.jasrep.2018.06.005

Decker M (2009) Plants and progress: Rethinking the islamic agricultural revolution. JWorld Hist 20:187-206. https://doi.org/10.1353/jwh.0.0058

Deng Z, Hung HC, Fan X et al (2018) The ancient dispersal of millets in southern China: new archaeological evidence. Holocene 28:34-43. https:// doi.org/10.1177/0959683617714603

Deng Z, Fuller DQ, Chu X et al (2020) Assessing the occurrence and status of wheat in late Neolithic central China: the importance of direct AMS radiocarbon dates from Xiazhai. Veg Hist Archaeobot 29:61-73. https:// doi.org/10.1007/s00334-019-00732-7

Ding Y (1957) The origin and evolution of Chinese cultivated rice. Journal of Agriculture 8(3):243-260

Diodorus S (1967 [60 BC]) Diodorus of Sicily in Twelve Volumes. Wlliam Heineman Ltd, Book II, London

Dioscorides P (2000) [AD 64]) De Materia Medica, (Edited and Introduction by Tess Anne Osbaldeston). Ibidis Press, Johannesburg, South Africa

Dueck D (2015) Megillos and rice-a note. The classical quarterly. Cambridge University Press, Cambridge 65(1): 377-384

Ehrlich R (1930) The Celebration and Gifts of the Persian New Year (Nawrūz) according to an Arabic Source. In: Dr. Modi Memorial Volume Editorial Board (ed) Dr. Modi Memorial Volume. Papers on Indo-Iranian and other subjects. Fort Printing Press, Bombay, pp 95-101

Ibn Fadlan (2012 [921]) Ibn Fadlan and the Land of Darkness Arab Travellers in the Far North. Paul Lunde and Caroline Stone (Trans.). Penguin Classics, London

Fairservis W (1975) The Roots of Ancient India, 2nd edn. The University of Chicago Press, Chicago, IL

Fang XL (1974 [AD 265-420]) Jinshu 晋书[Book of the Jin Dynasty]. Zhonghua shuju, Beijing

FAO (2020) Food Outlook - Biannual Report on Global Food Markets, June 2020FAO (2020) Food Outlook - Biannual Report on Global Food Markets: June 2020. Food Outlook,1. Romehttps://doi.org/10.4060/ ca9509en

Fazl AA (1873-1907 [1597]) The Aín I Akbari. Asiatic Society of Bengal and the Baptist Mission Press, Calcutta

Feliks Y (1963) Rice. Bar Ilan, sefer ha-shanah le-mada'e ha-Yahadut yeha-ruah shel Universițah Bar-Ilan. Bar-Ilan University Press (Hebrew), Ramat-Gan, pp 177-189

Feliks Y (2008) 'Rice'In:Encyclopedia Judaica. https://www.jewishvirtuallibrary. org/rice

Fujiwara H (1993) Research into the History of Rice Cultivation Using Plant Opal Analysis. In: Pearsall DM, Piperno DR (eds) Current research in phytolith analysis: applications in archaeology and palaeoecology. University of Pennsylvania Museum, Philadelphia, pp 147-158

Fujiwara H, Mughal MR, Sasaki A et al (1992) Rice and Ragi at Harappa: preliminary results by plant opal analysis. Pakistan Archaeology 27:129-142
Fuks D, Amichay O, Weiss E (2020) Innovation or preservation? Abbasid aubergines, archaeobotany, and the Islamic Green Revolution. Archaeol Anthropol Sci. https://doi.org/10.1007/s12520-019-00959-5

Fuller DQ (2002) Fifty Years of Archaeobotanical Studies in India: laying a solid foundation. In: Settar S, Korisettar R (eds) Indian archaeology in retrospect iil: Archaeology and Interactive Disciplines. Manohar, New Delhi, pp 247-364

Fuller DQ (2005) Ceramics, seeds and culinary change in prehistoric India. Antiquity 79:761-777. https://doi.org/10.1017/S0003598X00114917

Fuller DQ (2006) Agricultural origins and frontiers in South Asia: a working synthesis. J World Prehistory 20:1-86. https://doi.org/10.1007/ s10963-006-9006-8

Fuller DQ (2011a) Pathways to Asian civilizations: Tracing the origins and spread of rice and rice cultures. Rice 4:78-92. https://doi.org/10.1007/ s12284-011-9078-7

Fuller DQ (2011b) Finding plant domestication in the Indian subcontinent. Curr Anthropol. https://doi.org/10.1086/658900

Fuller DQ, Madella M (2002) Issues in Harappan Archaeobotany: retrospect and prospect. In: Settar S, Korisettar R (eds) Indian Archaeology in Retrospect II: Protohistory. Manohar, New Delhi, pp 317-390

Fuller DQ, Qin L (2009) Water management and labour in the origins and dispersal of Asian rice. World Archaeol 41:88-111. https://doi.org/10. 1080/00438240802668321

Fuller DQ, Rowlands M (2011) Ingestion and food technolo- gies: Maintaining differences over the long-term in West, South and East Asia. In: Bennet J, Sherratt S Wilkinson TC Interweaving Worlds - Syst Interact Eurasia, 7th to 1st Millenn B (Essays from a Conf Mem Profr Andrew Sherratt) Oxford, pp 36-67

Fuller DQ, Weisskopf A (2011) The early rice project: from domestication to global warming. Archaeol Int 13:44-51. https://doi.org/10.5334/ai.1314

Fuller DQ, Harvey E, Qin L (2007) Presumed domestication? Evidence for wild rice cultivation and domestication in the fifth millennium $B C$ of the Lower Yangtze region. Antiquity 81:316-331. https://doi.org/10.1017/ S0003598X0009520X

Fuller DQ, Qin L, Harvey EL (2009) An evolutionary model for Chinese rice domestication: reassessing the data of the Lower Yangtze region. New Approaches to Prehist Agric 312-345

Fuller DQ, Sato YI, Castillo C et al (2010) Consilience of genetics and archaeobotany in the entangled history of rice. Archaeol Anthropol Sci 2:115-131. https://doi.org/10.1007/s12520-010-0035-y

Fuller DQ, van Etten J, Manning K et al (2011) The contribution of rice agriculture and livestock pastoralism to prehistoric methane levels: An archaeological assessment. Holocene 21:743-759. https://doi.org/10. 1177/0959683611398052

Fuller DQ, Denham T, Arroyo-Kalin M et al (2014) Convergent evolution and parallelism in plant domestication revealed by an expanding archaeological record. Proc Natl Acad Sci U S A 111:6147-6152. https://doi.org/ 10.1073/pnas.1308937110

Ghosh R, Gupta S, Bera S et al (2008) Ovi-caprid dung as an indicator of paleovegetation and paleoclimate in northwestern China. Quat Res 70:149-157. https://doi.org/10.1016/j.yqres.2008.02.007

Gorbunova NG(1986) The culture of ancient Ferghana: VI century B.C. - VI century A.D., A. P. Andryushkin (Trans.). BAR International Series 281: Oxford.

Gowdy J, Krall L (2014) Agriculture as a major evolutionary transition to human ultrasociality. J Bioeconomics 16:179-202. https://doi.org/10.1007/ s10818-013-9156-6

Grehan J (2007) Everyday Life and Consumer Culture in Eighteenth-Century Damascus. University of Washington Press, Seattle

Gross BL, Zhao Z (2014) Archaeological and genetic insights into the origins of domesticated rice. Proc Natl Acad Sci U S A 111:6190-6197. https://doi. org/10.1073/pnas.1308942110

Guo WT (1982) 郭文蹈 中国古代的轮作制和耕作法 [Rotation and Tillage in Ancient China], 农业出版社[Agricultural Press]

Hallock RT (1969) Persepolis fortification tablets. University of Chicago Press, Chicago

Han J (2012) The painted pottery road' and early Sino-Western cultural exchanges. Anabasis 3:25-42

Harvey EL, Fuller DQ (2005) Investigating crop processing using phytolith analysis: the example of rice and millets. J Archaeol Sci 32:739-752. https://doi.org/10.1016/j.jas.2004.12.010 
Harvey EL, Fuller DQ, Pal JN et al (2005) Early agriculture of Neolithic Vindhyas (North-Central India). In: Franke-Vogt U, Weisshaar J (eds) South Asian Archaeology 2003 (Proceedings of the European Association for South Asian Archaeology Conference, Bonn: 7th-11th July 2003). Linden Soft, Aachen, pp 329-334

He K, Lu H, Zhang J et al (2017) Prehistoric evolution of the dualistic structure mixed rice and millet farming in China. Holocene 27:1885-1898. https://doi.org/10.1177/0959683617708455

Herodotus, (1987) [440 BC]) The History, translated by David Gren. University of Chicago Press, Chicago

Hill JE (2009) Through the Jade Gate to Rome. A study of the silk routes during the Later Han Dynasty (1st to 2nd centuries CE): an annotated translation of the chronicle on the "Western Regions" from the Hou Hanshu. Book Surge Publishing, Charleston, South Carolina

Horace (2008 [35 BC]) The Satires of Horace. Juster, A.M. (Trans.). University of Pennsylvania Press, Philadelphia

Hosner D, Wagner M, Tarasov PE et al (2016) Spatiotemporal distribution patterns of archaeological sites in China during the Neolithic and Bronze Age: an overview. Holocene 26:1576-1593. https://doi.org/10.1177/ 0959683616641743

Huang X, Kurata N, Wei X et al (2012) A map of rice genome variation reveals the origin of cultivated rice. Nature 490:497-501. https://doi.org/10. 1038/nature 11532

Ibn al-Faqīh (1885) Mukhtașar kitāb al-buldān (Compendium libri Kitāb Al-Boldān). Brill, Leiden

Ibn al-Nadìm, Muḥammad ibn Isḥāq (1871-1872) Kitâb al-Fihrist. Gustav Flügel (Trans.). F.C.W. Vogel, Leipzig

Jahangir (1909-1914 [1569-1627]) The Tūzuk-i-Jahangîri:: Memoirs of Jahāngìr (Tuzk-e-Jahangiri). Royal Asiatic Society, London

Jeong C, Ozga AT, Witonsky DB et al (2016) Long-term genetic stability and a high-altitude East Asian origin for the peoples of the high valleys of the Himalayan arc. Proc Natl Acad Sci 113:7485-7490. https://doi.org/10. 1073/pnas.1520844113

Jiang L, Liu L (2006) New evidence for the origins of sedentism and rice domestication in the Lower Yangzi River, China. Antiquity 80:355-361. https://doi.org/10.1017/S0003598X00093674

Jin GY, Wu WW, Zhang KS, Wang ZB, Wu XH (2014) 8000-Year old rice remains from the north edge of the Shandong Highlands, East China. J Archaeol Sci 51:34-42

Johns J (1984) A green revolution? J Afric Hist 25:344

Kajale MD (1982) Early agricultural in Kashmir Valley: Palaeobotanical evidence from recent excavations at Gufkral, Dist. Pulwama, Jammu \& Kashmir. In an International Workshop on the Late Cenozoic Palaeoclimatic Changes in Kashmir and Central Asia, pp 19-23

Kawakami SI, Ebana K, Nishikawa T et al (2007) Genetic variation in the chloroplast genome suggests multiple domestication of cultivated Asian rice (Oryza sativa L.). Genome 50:180-187. https://doi.org/10.1139/G06-139

Kennedy $\mathrm{H}$ (2011) The feeding of the five hundred thousand: cities and agriculture in early Islamic Mesopotamia. Iraq 73:177-199. https://doi.org/ 10.1017/s0021088900000152

Kitāb al-mahāsin wa'l-aḍdād, ed. (1898) G. Van Vloten (=Le livre des beautés et des antithèses attribué à Abu Othman Amr ibn Bahr al-Djahiz de Basra). Brill, Leiden

Knörzer KH (1966) Über Funde römischer Importfrüchte in Novaesium (Finds of Imported Roman Fruits at Novaesium). Bonner Jahrbücher (bonn Annals) 166:433-443

Knörzer KH (1970) Römerzeitliche Pflanzenreste aus Neuss (Roman plant remains from Neuss). Novaesium 4. Gebrüder Mann Verlag, Berlin, pp $1-128$

Kovach MJ, Sweeney MT, McCouch SR (2007) New insights into the history of rice domestication. Trends Genet 23:578-587. https://doi.org/10.1016/j. tig.2007.08.012

Laufer B, Sino-Iranica, (1919) Chinese contributions to the history of civilization in ancient Iran, with special reference to the history of cultivated plants and products. The Field Museum of Natural History, Chicago

Li YS (2018) AD 643-659]) Beishi 北史 [History of the Northern Dynasties. Yiya Press, Beijing

Li X, Zhang Y (2006) 新疆吐鲁番地区阿斯塔那古墓群西区408, 409号墓 [Tombs 408 and 409 of the western part of the Astana cemetery in Turpan, Xinjiang]. Kaogu 12:3-11
Li Y, Storozum MJ, Wang X, Guo W (2017) Early irrigation and agropastoralism at Mohuchahangoukou (MGK), Xinjiang, China. Archaeol Res Asia 12:23-32. https://doi.org/10.1016/j.ara.2017.09.005

Linghu DF (2018) AD 636]) Zhoushu 周书 [Book of Zhou. Yiya Press, Beijing Liu L (2004) The Chinese neolithic. Cambridge University Press, Cambridge

Liu X, Jones PJ, Motuzaite Matuzeviciute G et al (2019) From ecological opportunism to multi-cropping: mapping food globalisation in prehistory. Quat Sci Rev 206:21-28. https://doi.org/10.1016/j.quascirev.2018.12.017

Lone FA, Khan M, Buth GM (1993) Palaeoethnobotany plants and ancient man in Kashmir. Oxford and 1BH Publishers, New Delhi

Löw I (1924) Die flora der Juden (The Flora of the Jews). R. Löwit, Berlin

Lu HY (2017) New methods and progress in research on the origins and evolution of prehistoric agriculture in China. Sci China Earth Sci 60:21412159. https://doi.org/10.1007/s11430-017-9145-2

Mac Gahan JA (1876) Campaigning on the Oxus and the Fall of Khiva. Sampson Low, Maeston, Searle, \& Rivington, London

Madella M (2014) Of Crops and Food, a social perspective on rice in the Indus Civilisation. In: Madella M, Lancelotti C, Savard M (eds) Ancient plants and people, contemporary trends in archaeology. University of Arizona Press, Tuscon, pp 218-236

Marton R (2014) Rice: a global history. Reaktion Books, London

Marvin C (1881) Merv: The Queen of the World: Scourge of the Man-Stealing Turcomans, with and Exposition of the Khorassan Question. W. H. Allen \& Co, London

Mayrhofer, Manfred (1976) Kurzgefasstes etymologisches Wörterbuch des Altindischen. Vol. 3, Y-H. Carl Winter.

McNally KL, Childs KL, Bohnert R, et al (2009) Genomewide SNP variation reveals relationships among landraces and modern varieties of rice. Proc Natl Acad Sci USA 106:12273-12278. https://doi.org/10.1073/pnas. 0900992106

Miller NF (1981) Plant Remains from Villa Royale II, Susa. Cahiers De La Délégation Archéologique Française En Iran 12:37-42

Miller NF (2011) An archaeobotanical perspective on environment, plant use, agriculture, and interregional contact in South and Western Iran. Iran J Archaeol Stud 1(2):1-8

Mir-Makhamad B, Mirzaakhmedov S, Rahmonov H, Stark S, Omel'chenko A, Spengler RN (upcoming) Qarakhanids on the Edge of Bukhara Oasis: Archaeobotany of Medieval Paykend. Manuscript submitted for publication to Economic Botany.

Morgenstierne G (2003) A new etymological vocabulary of Pashto: Beiträge zur Iranistik

Muthukumaran S (2014) Between archaeology and text: the origins of rice consumption and cultivation in the middle east and the Mediterranean. Pap from Inst Archaeol 24:1-7. https://doi.org/10.5334/pia.465

Narasimhan VM, Patterson N, Moorjani P et al (2019) The formation of human populations in South and Central Asia. Science 80:365. https://doi.org/ 10.1126/science.aat7487

Nasrallah N (2007) Annals of the Caliphs' Kitchens. Brill, Leiden, The Netherlands

Nasrallah N (2018) Treasure trove of benefits and varieties at the table: a fourteenth-century Egyptian Cookbook. Brill, Boston

Naveh J, Shaked S (eds) (2012) Aramaic Documents from Ancient Bactria (Fourth Century BCE) from the Khalili Collections. Khalili Family Trust, London

Nesbitt M, Simpson SJ, Svanberg I (2010) History of rice in Western and Central Asia. In: Sharma SD (ed) Rice: origin, antiquity and history. Science Publishers, Enfield, pp 308-340

Olivieri L (2018) Vajīrasthāna/Bazira and beyond: Foundation and current status of the archaeological work in Swat. In: Buddhism and Gandhara: an archaeology of museum collections. Himanshu Prabha Ray (ed) Routledge India, London

Olivieri LM (2020) Gandhāra and North-Western India. In R. Mairs, ed., The Graeco-Bactrian and Indo-Greek World, Routledge, London-New York. https://doi.org/10.4324/9781315108513-19

Olivieri LM, Marzaioli F, Passariello I et al (2019) A new revised chronology and cultural sequence of the Swat valley, Khyber Pakhtunkhwa (Pakistan) in the light of current excavations at Barikot (Bir-kot-ghwandai). Nucl Instruments Methods Phys Res Sect B Beam Interact Mater Atoms 456:148-156. https://doi.org/10.1016/j.nimb.2019.05.065 
Omrak A, Günther T, Valdiosera C et al (2016) Genomic evidence establishes anatolia as the source of the European Neolithic Gene Pool. Curr Biol 26:270-275. https://doi.org/10.1016/j.cub.2015.12.019

Perry C (2017) Scents and Flavors the Banqueter Favors (Kitab al-Wuslah ila I-Habib fi Wasf al-Tayyibat wal-Tib), New York: New York University Press, thirteenth century

Peterson T (1980) The Arabn influence on Western European cooking. J Mediev Hist 6(3):317-340

Petrie CA, Bates J (2017) 'Multi-cropping', intercropping and adaptation to variable environments in Indus South Asia. J World Prehistory 30:81-130. https://doi.org/10.1007/s10963-017-9101-z

Petrushevskii IP (1960) Земледелие и аграрные отношения в Иране XII-XIV веков (Agriculture and agrarian relations in Iran in the XIII-XIV centuries). Moskow/Leningrad: Издательство AН СССР (Publishing house of the Academy of Sciences of the USSR)

Peyrot M (2018) "Tocharian Agricultural Terminology". In Kroonen, Mallory \& Comrie (eds). Talking Neolithic, pp 242-277

Pliny and Elder (1855 [AD 77-79]) Naturalis Historia (The Natural History). Taylor and Francis, London

Pokharia AK, Sharma S, Tripathi D et al (2017) Neolithic-Early historic (2500-200 BC) plant use: the archaeobotany of Ganga Plain, India. Quat Int 443:223-237. https://doi.org/10.1016/j.quaint.2016.09.018

Pokharia AK, Mani BR, Spate M et al (2018) Early Neolithic agriculture (2700$2000 \mathrm{bc}$ ) and Kushan period developments (ad 100-300): macrobotanical evidence from Kanispur in Kashmir, India. Veg Hist Archaeobot 27:477-491. https://doi.org/10.1007/s00334-017-0645-8

Possehl GL (1999) Indus age: the beginnings. University of Pennsylvania Press, Philadelphia

Rabin C (1966) Rice in the Bible. J Semit Stud 9:2-9

Rashīd al-Dīn Faḍl Allāh Hamadānī (1989) Āthār wa Ahyā’. Matn-i fārsī darbāra-i fann-i kishāwarz. Dānishgāh, Tihrān

Ray DK, Navin R, Mueller NB, West PC, Foley JA (2021) Recent patterns of crop yield growth and stagnation. Nat Commun 3:1293.

Reed K, Leleković T (2019) First evidence of rice (Oryza cf. sativa L.) and black pepper (Piper nigrum) in Roman Mursa. Croatia Archaeol Anthropol Sci 11:271-278. https://doi.org/10.1007/s12520-017-0545-y

Rosen AM, Chang C, Grigoriev FP (2000) Palaeoenvironments and economy of Iron Age Saka-Wusun agro-pastoralists in southeastern Kazakhstan. Antiquity 74:611-623. https://doi.org/10.1017/S0003598X00059974

Safrai Z (1994) The economy of Roman Palestine. Routledge, London

Samuel D (2001) Archaeobotanical Evidence and Analysis, in Mission Mésopotamie syrienne - Archéologie islamique (1986-1989) Peuplement Rural et Aménagments Hydroagricoles dans la Moyenne Vallée de I'Eurphrate Fin VIle- XIXe Siécle, S. Berthier, L. Chaix, J. Studer, O. D'Hont, R. Gyselend and D. Samuel, Eds., Damascus, Syria, Institut Francais de Damas, pp 347-481

Saraswat KS (2005) Agricultural background of the early farming communities in the Middle Ganga Plain. Pragdhara 15:145-177

Saraswat KS, Pokharia AK (2003) Palaeoethnobotanical investigations at Early Harappan Kunal. Pragdhara 12:105-140

Saxena A, Prasad V, Singh IB et al (2006) On the Holocene record of phytoliths of wild and cultivated rice from Ganga Plain: Evidence for rice-based agriculture. Curr Sci 90:1547-1552

Schuyler E (1877) Turkistan: Notes of a Journey in Russian Turkistan, Khokand, Bukhara, and Kuldja, vol 1. Scribner, Armstrong \& Co, New York

Schoff WH (ed.) (1912) The Periplus of the Erythraean Sea: Travel and Trade in the Indian Ocean by a Merchant of the First Century. Longmans, Green, \& Co, New York

Sharif M, Thapar BK (1992) Food-producing communities in Pakistan and Northern India. In: Dani AH and Masson VM (eds) History and Civilizations of Central Asia: The Dawn of Civilization: Earliest times to 700 B.C, vol. 1. Paris: UNESCO, p. 127-151

Shih, Shêng-han (1959). On "Fan Shêng-chih Shu": an agriculturist book of China Written in the First Century B.C, Science Press.

Silva F, Stevens CJ, Weisskopf A et al (2015) Modelling the geographical origin of rice cultivation in Asia using the rice archaeological database. PLoS ONE 10:1-21. https://doi.org/10.1371/journal.pone.0137024

Silva F, Weisskopf A, Castillo C et al (2018) A tale of two rice varieties: Modelling the prehistoric dispersals of japonica and proto-indica rices. Holocene 28:1745-1758. https://doi.org/10.1177/0959683618788634
Sima Q (1993) 109-91 BC]) Shiji 史记 [Records of the Grand Historian. Yiya Press, Beijing

Simoons FJ (1990) Food in China: a cultural and historical inquiry. CRC Press, Boca Roton

Sims-Williams N (2012) Bactrian historical inscriptions of the Kushan period. Silk Road 10:76-80

Soares P, Olalde I, Mallick S et al (2019) The genomic history of the Iberian Peninsula over the past 8000 years. Science(80-) 1234:1230-1234

Song J, Lu H, Zhang Z, Liu X (2018) Archaeobotanical remains from the midfirst millennium AD site of Kaerdong in western Tibet. Archaeol Anthropol Sci 10:2015-2026. https://doi.org/10.1007/s12520-017-0521-6

Spengler RN, Miller NF, Neef R et al (2017) Linking agriculture and exchange to social developments of the Central Asian Iron Age. J Anthropol Archaeol 48:295-308. https://doi.org/10.1016/j.jaa.2017.09.002

Spengler RN, Tang L, Nayak A et al (2020) The southern Central Asian mountains as an ancient agricultural mixing zone: new archaeobotanical data from Barikot in the Swat valley of Pakistan. Veg Hist Archaeobot. https:// doi.org/10.1007/s00334-020-00798-8

Squatriti P (2014) Of seeds, seasons, and seas: andrew watson's medieval agrarian revolution forty years later. J Econ Hist 74:1205-1220

Stacul G (1976) Excavation at Loebanr III (Swāt, Pakistan). East and West 26(1):13-30

Stacul G (1993) Kalako-deray, Swat: 1989-1991 Excavation report. East West 43(1-4):69-94

Stadler RE (1914) Reis. In Paulys Realencyclopädie der Classischen Altertumswissenschaft (Paulys Encyclopedia of Classical Antiquity). Zweite Reihe and Erster Halbband (Eds.) (pp. 515-522) J. B. Stuttgart: Metzlersche Verlagsbuchhandlung

Stevens CJ, Murphy C, Roberts R et al (2016) Between China and South Asia: a middle Asian corridor of crop dispersal and agricultural innovation in the Bronze Age. Holocene 26:1541-1555. https://doi.org/10.1177/ 0959683616650268

Strabo (1924 [7 BC-AD 23]) The Geography of Strabo. Harvard University Press, Cambridge, Massachusetts

Sumner WM, Whitcomb D (1999) Islamic settlement and chronology in fars: an archaeological perspective. Iran Antiq 34:309-324. https://doi.org/ 10.2143/IA.34.0.519117

Tassinari P (2019) Galen: Works on Human Nature (Cambridge Galen Translations) (P. Singer \& P. Van der Eijk, Eds.). Cambridge University Press, Cambridge

Tavernier J (2007) Iranica in the Achaemenid Period (ca. 550-330 B.C.). Lexicon of old Iranian proper names and loanwords, attested in nonIranian texts. Leuven/Paris/Dudley, MA: Peeters. Available at: https:// catalog.hathitrust.org/Record/005564891?signon=swle:urn:mace: incommon:nyu.edu

Tewari R, Srivastava RK, Saraswat KS, Singh IB, Singh KK (2008) Early Farming at Lahuradewa Pragdhara 18:347-373

Theophrastus (1916 [ca. 350-287 BC]) Enquiry into Plants, Book I-V, Loeb Classical Library/G.P. Putnam's Sons, New York

Usmanova ZI (1963) Erk-Kala (po materialam YuTAKE 1955-1959 gg.). Trudy YUTAKE 12: 20-94. Ashkhabad

Van der Veen M (2011) Consumption, Trade and Innovation: Exploring the Botanical Remains from the Roman and Islamic Ports at Quseir al-Qadim, Egypt. Journal of African Arcaheology Monograph Series, Africa Magna Verlag, Frankfurt

Van der Veen M, Bouchaud C, Cappers R, Newton C (2018). Roman Life in the Eastern Desert of Egypt: food, imperial power and geopolitics. In: Jean-Pierre Brun (ed.), The Eastern Desert of Egypt during the GrecoRoman Period: archaeological reports. Collège de France, Paris

Van Der Veen M, Morales J (2015) The Roman and Islamic spice trade: new archaeological evidence. J Ethnopharmacol 167:54-63. https://doi. org/10.1016/j.jep.2014.09.036

Vaughan DA, Lu BR, Tomooka N (2008) Was Asian rice (Oryza sativa) domesticated more than once? Rice 1:16-24. https://doi.org/10.1007/ s12284-008-9000-0

Vidale M, Olivieri L (2002) Painted rock shelters of the Swat Valley: Further discoveries and new hypotheses. East West 52:173-223

Vidale M, Micheli R, Olivieri L (2011) Iconography of Protohistoric Swāt and the Agricultural Intensification of Period IV (2nd Millennium BCE) Iconography of Protohistoric Swāt. 34:79-103. 
Vidale M, Olivieri L, Micheli R (Eds) (2015) Excavations at the protohistoric graveyards of Gogdara and Udegram. Sang-e-Meel Publications

Watson AM (1983) Agricultural Innovation in the Early Islamic World. Cambridge University Press, Cambridge

Wei D et al. (2018 [AD 551-554]) Weishu 魏书 [Book of Wei]. Yiya Press, Beijing

Witzel M (1995) Early Indian history: Linguistic and textual parameters. In: Erdosy G (ed) The Indo-Aryans of Ancient South Asia: Language, Materal Culture and Ethnicity. De Gruyter, pp 85-125

Yang J (2014) Some clues of the Hellenistic world and the Roman East Hidden in China's early four historical books. Talanta 46-47:212-143

Yu T (2013) A history of the relationship between the Western \& Eastern Han, Wei, Jin. Department of East Asian Languages and Civilizations, University of Pennsylvania, Pennsylvania, Northern \& Southern Dynasties and the Western Regions

Zach B (2002) Vegetable offerings on the Roman sacrificial site in Mainz, Germany-short report on the first results. Veg Hist Archaeobot 11:101-106

Zaouali LL (2009) Medieval cuisine of the islamic world: a concise history with 174 recipes. California studies in food and culture. University of California Press, Berkeley.

Zhang A, Tian H (2015) The remains of the site the layout of the defense cities of the Han dynasty in the Western Regions. J Chin Hist Geogr 30:47-55

Zhang J, Lu H, Wu N et al (2010) Phytolith evidence for rice cultivation and spread in Mid-Late Neolithic archaeological sites in central North China. Boreas 39:592-602. https://doi.org/10.1111/j.1502-3885.2010.00145.x

Zhang J, Lu H, Gu W, et al (2012) Early Mixed Farming of Millet and Rice 7800 Years Ago in the Middle Yellow River Region, China. PLoS ONE. https:// doi.org/10.1371/journal.pone.0052146

Zhao Z (2011) New archaeobotanic data for the study of the origins of agriculture in China. Curr Anthropol 52:295-306. https://doi.org/10.1086/ 659308

Zheng Y, Jiang L, Zheng J (2004) Study on the Remains of Ancient Rice from Kuahuqiao Site in Zhejiang Province. Chin J Rice Sci 18:119-124

Zheng Y, Crawford GW, Jiang L, Chen X (2016) Rice domestication revealed by reduced shattering of archaeological rice from the Lower Yangtze valley. Sci Rep 6:1-9. https://doi.org/10.1038/srep28136

Zohary D (1998) The diffusion of South and East Asian and of African crops into the belt of Mediterranean agriculture, In: Prendergast HDV, Etkin $\mathrm{NL}$, Harris DR, et al (eds) Plants for food and medicine. Royal Botanic Gardens, Kew, London, pp 123-134

Zuo X, Lu H, Jiang Let al (2017) Dating rice remains through phytolith carbon-14 study reveals domestication at the beginning of the Holocene. Proc Natl Acad Sci 114:6486-6491. https://doi.org/10.1073/pnas.17043 04114

\section{Publisher's Note}

Springer Nature remains neutral with regard to jurisdictional claims in published maps and institutional affiliations.

\section{Submit your manuscript to a SpringerOpen ${ }^{\circ}$ journal and benefit from:}

- Convenient online submission

- Rigorous peer review

- Open access: articles freely available online

- High visibility within the field

- Retaining the copyright to your article

Submit your next manuscript at $\boldsymbol{\nabla}$ springeropen.com 